\title{
IEA HPP ANNEX 41 - COLD CLIMATE HEAT PUMPS: Task 1 Report - Literature and Technology Review - United States
}

\author{
V. Baxter ${ }^{\mathrm{a}}$, E. Groll ${ }^{\mathrm{b}}$, O. Abdelaziz ${ }^{\mathrm{a}}$, B. Shen ${ }^{\mathrm{a}}, \mathrm{G}$. Groff $^{\mathrm{c}}$, K. Sikes $^{\mathrm{d}}, \mathrm{G}$. Khowailed $^{\mathrm{d}}$ \\ ${ }^{a}$ Oak Ridge National Laboratory \\ ${ }^{\mathrm{b}}$ Herrick Labs, Purdue University \\ ${ }^{\circ}$ Groff Associates \\ ${ }^{d}$ SRA International, Inc.
}

\section{INTRODUCTION}

During the mid-1970s, following the first oil embargo, heat pumps became of great interest to northern U. S. electric power companies, particularly for those experiencing large peak demands during the heating season, as shortages of natural gas and oil led to increased usage of direct electric heating. Air-source heat pumps (ASHP), given their wider market presence relative to other heat pump types, almost universal applicability, and inherent efficiency and capacity issues at cold outdoor temperatures were of primary interest as an electrical heating system alternative at that time. ASHPs based on the simple vapor compression cycle suffer both heating capacity (output) and efficiency (coefficient of performance or COP) degradation as the outdoor ambient temperature drops. At the same time, building heat demand is increasing so ASHPs require a supplemental heating source - usually direct electric resistance heating elements - to bridge the gap between the building heat demand and the ASHP heating output. This feature causes lower seasonal performance and limits peak electric demand reduction potential leading to limited acceptance of ASHPs in areas that experience large numbers of hours at cold temperatures (loosely defined as $\leq-7^{\circ} \mathrm{C}$ for purposes of Annex 41). A primary criterion for ASHPs to achieve good seasonal performance in cold areas is achieving high heating output at low ambient temperatures so as to minimize reliance on supplemental heat sources and maximize the overall system heating seasonal performance factor (HSPF or SPF $)$.

With increasing concern for technology options that can result in reduced $\mathrm{CO}_{2}$ emissions, it is appropriate to revisit research and development work undertaken in different countries on heat pump systems for cold climates and to examine technology improvements that could lead to expanded usage of electric heat pumps for applications in cold regions. Accordingly, in 2010 the U. S. Department of Energy's Building Technology Office (DOE/BTO) solicited R\&D proposals focused on advancing heat pump technology for cold climate applications. The performance targets specified in the solicitation are listed in Table 1 below.

Table 1: U. S. DOE cold climate heat pump performance targets

\begin{tabular}{|c|c|c|}
\hline Outdoor Temperature & Heating COP & Heating Capacity \\
\hline $8.3^{\circ} \mathrm{C}\left(47^{\circ} \mathrm{F}\right)$ & 4.5, nominal rating & $14 \mathrm{~kW}(48,000 \mathrm{Btu} / \mathrm{h})$, nominal rating \\
\hline$-25^{\circ} \mathrm{C}\left(-13^{\circ} \mathrm{F}\right)$ & $\leq 50 \%$ reduction from nominal & $\leq 25 \%$ reduction from nominal \\
\hline
\end{tabular}

At the same time, the U. S. proposed to the IEA Heat Pump Programme (IEA HPP) that a new Annex be established to collaborate with other HPP members to improve performance of heat pumps for cold climates. Annex 41 was officially approved in May of 2012. The principal focus of Annex 41 is on electrically driven ASHPs since that system type has the biggest performance 
challenges given its inherent low ambient temperature performance problems alluded to above. However, the Annex is open to ground source heat pumps and natural gas (engine or sorption) driven ASHPs as well at the Participants' discretion. Availability of heat pump systems with improved low ambient performance would help bring about a much stronger heat pump market presence in cold areas which today rely predominantly on fossil fuel furnace heating systems. A primary technical objective of the Annex is to define pathways to enable ASHPs to achieve an "in field" heating $\mathrm{SPF}_{\mathrm{h}} \geq 2.63 \mathrm{~W} / \mathrm{W}$ (HSPF $\geq 9.0 \mathrm{Btu} / \mathrm{Wh}$ ), the minimum level necessary in order to gain recognition as a renewable technology in the EU.

The U. S. Department of Defense (DOD) has estimated that buildings accounted for $24 \%$ of its energy consumption in 2007 (U.S. DOD WSTIAC, 2009). Several mandates, including Executive Order 13514, "Federal Leadership in Environmental, Energy, and Economic Performance" (EO 13514, 2009), calling for the improvement on the efficiency of federal buildings are affecting the current and future stock of DOD buildings. The use of heat pumps designed for cold climates is a promising approach to improve the HVAC efficiencies to aid compliance with these mandates. The goals are to create a clean energy economy that the Federal Government will lead by example. One significant goal is mandatory energy reductions to reach net-zero-energy buildings by 2030 (EO 13514). The Energy Independence and Security Act of 2007 includes Section 315, "Improved Energy Efficiency for Appliances and Buildings in Cold Climates" specifically addressing advancements for cold climates. One requirement of the act is the reduction of fossil fuels in new or renovated buildings, $55 \%$ by 2010 then $100 \%$ by 2030 (EISA, 2007).

In May of 2006, the Secretary of Defense commissioned an Energy Security Task Force, ESTF, to develop a roadmap to reduce the fossil fuels requirement for the DOD. A heat pump designed for cold climates has the ability to replace fossil fuel heating methods with an efficient, electricity based system. The energy reductions can grow even larger when the electricity is produced from renewable energy sources.

\section{BACKGROUND - ENERGY USE AND INCREASING ENERGY PRICES}

World energy consumption is projected to increase by $53 \%$ from about 530 EJ (505 quads) in 2008 to 810 EJ (770 quads) in 2035 (Conti et al., 2011). Energy consumption by Organization for Economic Co-operation and Development (OECD) member countries is projected to increase by only $18 \%$ while that by non-OECD countries is projected to increase by $85 \%$ over this time span. Due to the increase in demand from non-OECD countries, it is expected energy prices will continue to increase from 2008 levels in spite of new developments in extraction methods such as fracking for natural gas or unconventional reserves such as oil tar sands. For the United States, current forecasts project the increase of energy prices (in 2011 dollars); Brent spot oil from $\$ 111$ per barrel in 2011 to $\$ 163$ per barrel in 2040 , Henry Hub spot natural gas below $\$ 4$ per million BTU through 2018 to $\$ 7.83$ per million BTU in 2040 , and mine mouth price of coal from \$2.04 per million BTU in 2011 to \$3.08 per million BTU in 2040 (EIA, 2013). In percentages, the increase in the cost of energy is $47 \%$ for oil, roughly $90 \%$ for natural gas, and $51 \%$ for coal. These projected increases in fossil fuel prices could lead to increases in electricity prices of similar magnitude as well. With increases in consumption and costs of this magnitude, the urgency for reductions in U.S. energy consumption becomes evident.

The buildings sector in the United States accounted for about 42 EJ (40 quads) of primary energy consumption ( $41 \%$ of the U. S. total) in 2010, making it the sector accounting for the largest consumption. The U. S. Energy Information Administration (EIA) projects this will 
increase by $17 \%$ by 2035 . Space heating is responsible for $22.5 \%$, or roughly 9.5 EJ (9 quads) of this consumption (DOE, 2011). Fossil fuels account for about 6.7 EJ (6.3 quads) or 70\% of the space heating energy consumption leaving a large potential for alternative heating methods employing electricity.

Offsetting the consumption of fossil fuels on-site with electricity presents an opportunity to utilize renewable sources for power generation. Heat pumps are efficient technologies that employ electricity to achieve space heating where the heat output is a multiplier of the power consumption. Heat pumps specifically designed for cold climates were one of 15 technologies selected for the refined study of the reduction of primary energy consumption of HVAC systems in commercial buildings (Roth et al., 2002). Business case analyses conducted by Oak Ridge National Laboratory predict a cumulative energy savings potential of $0.53 \mathrm{EJ}$ ( 0.5 quads) from 2015 to 2030 for a cold climate heat pump assuming a 25\% penetration rate when compared to conventional electric heat pump and electric resistance units (Khowailed et al., 2011).

\section{BRIEF U. S. HEAT PUMP MARKET HISTORY}

\subsection{National Shipments \& Trends}

Since heat pump sales first emerged as a significant alternative for space heating and cooling of buildings during the 1950s, market sales have experienced significant volatility originating from:

- Government efficiency regulations and test methods

- Government and utility incentives for heat pumps

- Modifications to international trade barriers

- Technological breakthroughs

- Major swings in the housing market

- Economic recessions

- Availability, cost and rate structures of electricity and natural gas

- Favorable customer and utility experiences with certain models

The section below provides a high level overview of how the heat pump market has evolved in the U.S. since its inception, accompanied by explanations of the underlying market drivers.

\subsubsection{0-1969}

Early growth of heat pumps was very rapid following the wide-scale acceptance of residential forced-warm air heating systems and central air conditioning, in addition to the potential for abundant, low-cost electricity that nuclear power could supply. However, sales were soon slowed substantially due to poor product reliability resulting from inexperience or inadequate product testing on the part of many manufacturers who attempted to capitalize on the emerging market opportunity (Groff and Ertinger, 1984).

\subsection{2 $1970-1989$}

Despite the negative experiences mentioned above, heat pump sales grew at modest rates, mostly in mild climate zones with low electric rates, up until 1973 when the first oil embargo occurred. From 1973 to 1978, heat pump sales (or shipments) grew from 100,000 to over 560,000 annually, as shown in Figure 1, and heat pumps began to gain traction in the colder northern climate areas where natural gas and heating oil dominated. In the same period, the 
fraction of heat pump sales to northern areas of the U. S. rose from $15 \%$ to over $35 \%$. The rise is significant because these areas accounted for $75 \%$ of U. S. space-heating energy use at the time (Groff and Ertinger, 1984).

A recession from 1979-1981 together with greater-than-expected availability of natural gas dampened the heat pump sales growth rate considerably. But by 1983, sales had reached 700,000 per year, and projections indicated that by 1990 they should reach 1,000,000 units annually (Groff and Ertinger, 1984). Continued availability of adequate natural gas supplies and relatively low gas prices vs. electricity generally dampened heat pump sales growth so that the $1,000,000$ annual sales level was not reached until the mid-1990's.

\section{$3.1 .31990-2009$}

The United States experienced a relatively small economic downturn in 2001. A surge in heat pump sales is seen in 2005, which analysts believe is directly tied to the government regulation to increase the minimum seasonal energy efficiency ratio (SEER) for heating and cooling equipment from 10 to 13 - a $30 \%$ improvement. The change, which went into effect in 2006 , caused an increase in equipment costs, and as a result, manufacturers in many cases chose to ship out as much inventory as possible in 2005 since this stock would not meet the new standard. The lasting impact of this change on the heat pump market continues to be felt since some manufacturers were unable to produce at full capacity in 2006 while still meeting the new standard.

Heat pump shipments, along with most HVAC shipments, were also significantly impacted by the economic recession as well as the associated housing market decline, beginning in 2007 and intensifying over the next couple of years. When new single-family home construction drops (63 percent reduction in four years), the demand for new heat pumps is also stifled. The resulting steep drop in heat pump shipments between 2007 and 2009 is seen in Figure 1 (AHRI, 2010-2013; AHRI, 2012).

Since construction of new houses fell considerably during this time period, only $22 \%$ of heat pumps sold were installed in new homes during 2009, this indicates growing heat pump sales for add-on and replacement applications that usually require lower investments (Lapsa and Khowailed, 2011). Furthermore, high energy prices led some consumers and businesses to make upgrades by replacing inefficient equipment, including heat pumps, which assisted sales.

\subsubsection{0 to present}

The heat pump market has shown resilience to the aforementioned housing crisis and economic downturn, with 2010-2012 shipments recovering somewhat from the 2009 low. Furthermore heat pump shipments appear to be recovering faster than gas furnaces, increasing their market share. Figure 2 displays how heat pump shipments compared to those of competing heating technologies for the period 1990 to 2012. Compared to the market peaks in 2005-2006, heat pump shipments have dropped by $\sim 17 \%$ while combined gas and oil furnace shipments are down by $\sim 35 \%$. 


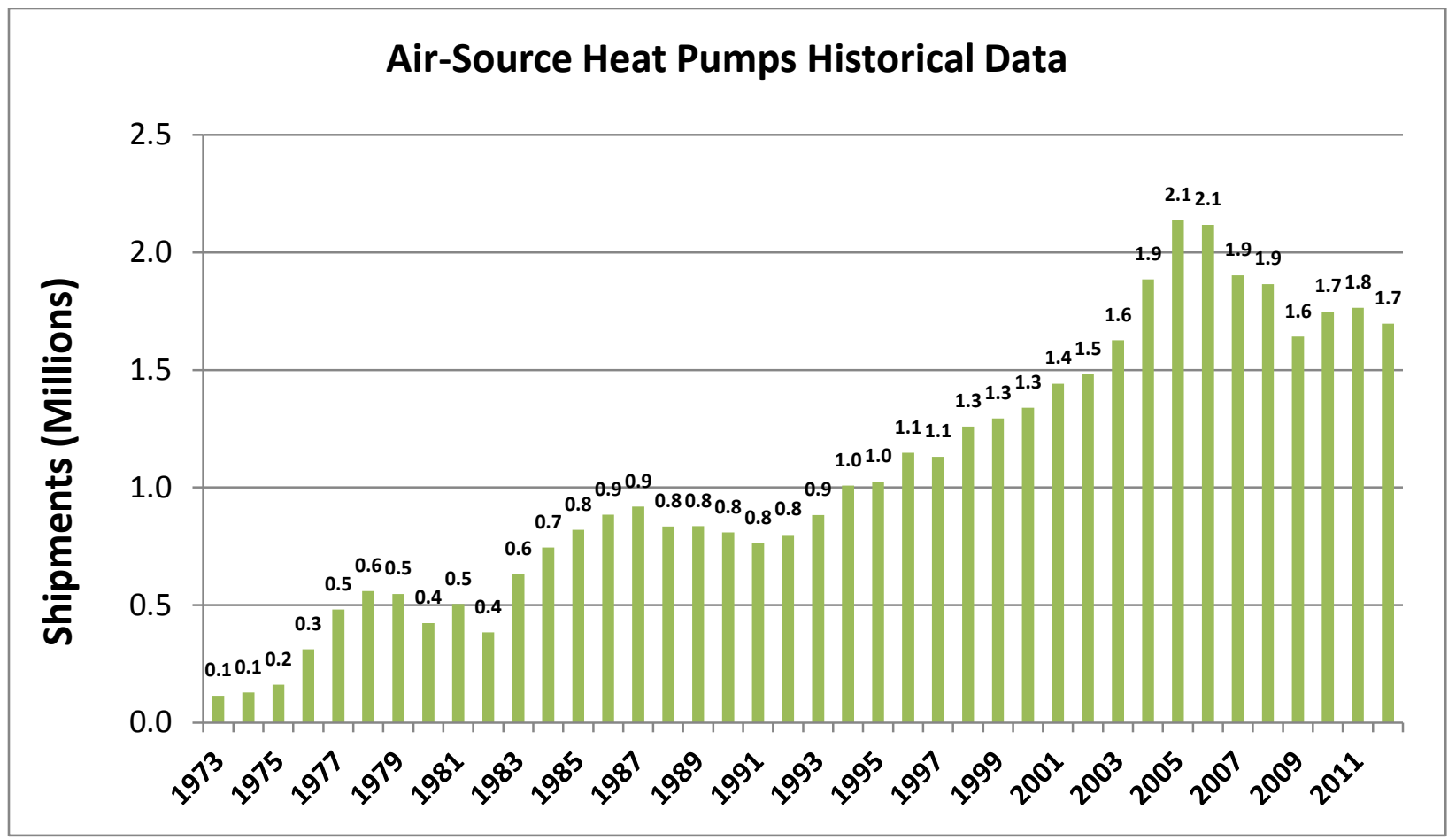

Figure 1: U.S. air source heat pump shipments (AHRI, 2010-2013)

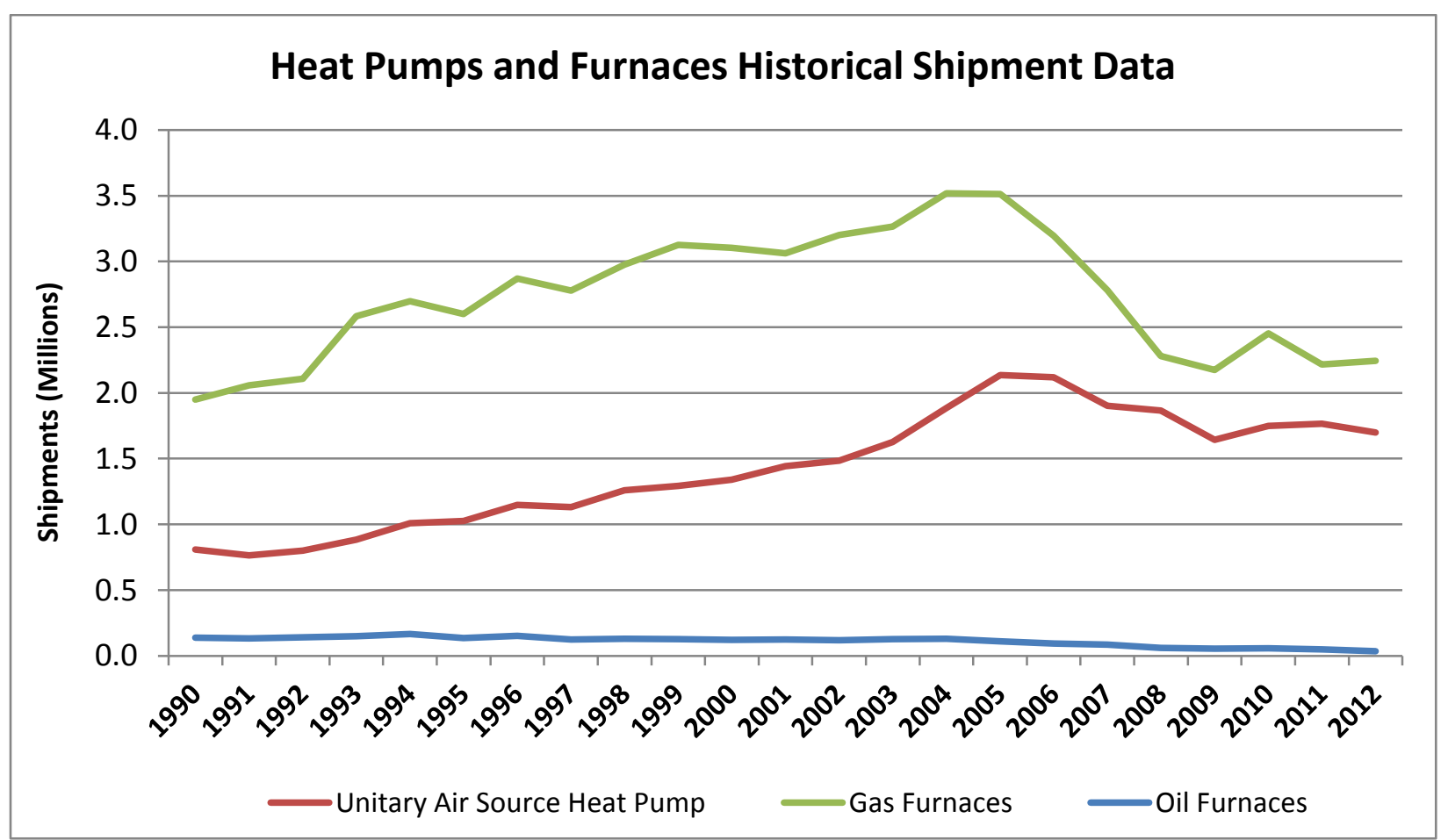

Figure 2: Unit shipments of heating equipment in the United States 


\subsection{Regional Shipments \& Trends}

The South U. S. census region has been best suited for heat pumps due to relatively lower electricity prices and moderate weather presenting a favorable market for ASHPs. The 2009 Residential Energy Consumption Survey (EIA, 2009) data highlights the primary heating equipment used in homes across the country. As of 2009, 9.8 million U.S. homes relied on heat pumps for their primary heating equipment, representing about $8.6 \%$ of the 114 million homes in the United States. A majority are in the South region with 7.5 million of the region's homes using heat pumps as their primary heating equipment (about $18 \%$ of the total 42 million homes located here).

Figure 3 provides a visual display of heat pump presence across the United States as of 2009. As indicated by the greener shades, the South clearly has the highest overall share of heat pump of all U.S. census regions. Within this region, the South Atlantic division shows the most penetration, with Virginia having the largest share of heat pump technologies among all the states (36\% of its 3 million homes use heat pumps as the primary heating technology). Heat pump penetration is not as high in the West South Central division of the South region, with only $4 \%$ of homes in Texas, Arkansas, Louisiana, and Oklahoma relying on heat pumps for their heating purposes. Only $2 \%$ of homes in the Northeast region use heat pumps, largely driven by 400,000 homes in Pennsylvania. Similarly, only $2 \%$ of homes in the Midwest region use heat pumps. The West region shows a somewhat stronger presence of heat pump technologies with about $5 \%$ of the homes currently using them as their primary heating system, mainly driven by 600,000 homes in Arizona. The relatively wider availability of natural gas to residential areas in the West South Central division and Northeast, Midwest, and West regions is at least partially responsible for the lower market share of electric heat pumps in those areas. It should be noted that the 18 states shaded grey in Figure 3 had insufficient data, either because no cases were in the reporting sample, data was withheld due to a Relative Standard Error (RSE) of the sample being greater than 50 percent, or fewer than 10 households were sampled. Based on the overall regional data described above however, the heat pump share of homes in these states is estimated at $<2 \%$.

The lower market presence of heat pumps in northern areas of the $U$. S. is not due to any inadequacy of heat pump performance or reliability. One of the authors of this report (Groff) has personal knowledge of individual electric heat pumps operating successfully in locales with winter temperatures reaching extremes as low as $-50^{\circ} \mathrm{C}\left(-58^{\circ} \mathrm{F}\right)$. Heat pump life studies sponsored by the Electric Power Research Institute (EPRI) covering heat pump installations in parts of nine U. S. states (Alabama, northern Illinois, Indiana, Kentucky, Michigan, Ohio, Tennessee, Virginia, and West Virginia) showed median heat pump service lifetimes ranging from $\sim 20.5$ years in southern locations to 15-16 years in northern locations (Lovvorn and Hiller, 2002; Lovvorn et al, 2001; Bucher et al, 1989; Pientka, 1987). Median life for the compressor from these studies was estimated at $\sim 13.5$ years in the Alabama studies indicating that no more than one compressor replacement was typically required during the service life of the heat pump installations surveyed (Lovvorn et al, 2001). Bucher et al, (1989) noted that for the heat pumps that required compressor replacement in their study, only $4.6 \%$ required more than one compressor replacement during their service lifetime. 


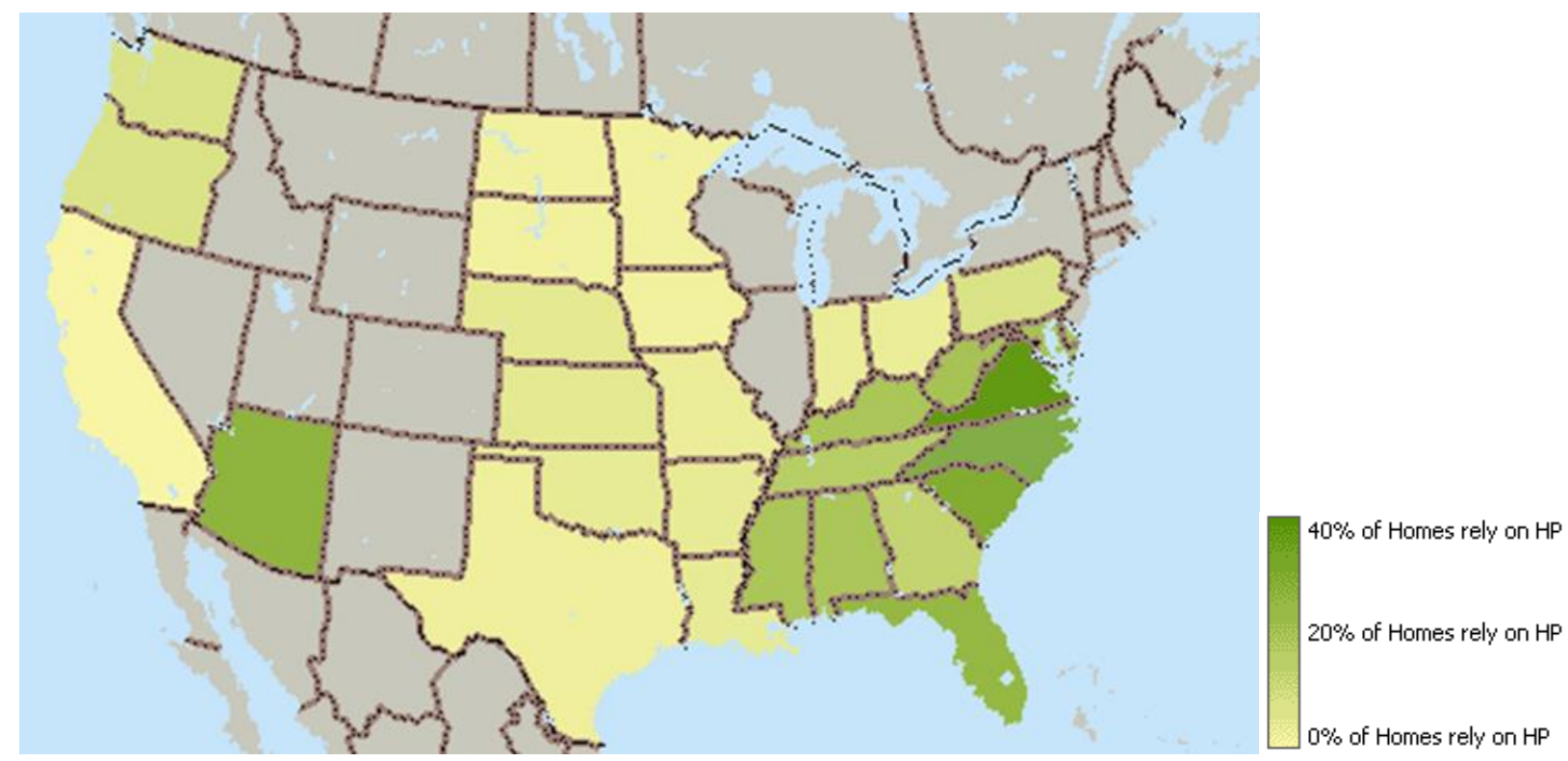

Figure 3: Percentage of homes using heat pump technology as the main heating equipment, as of 2009 (EIA, 2009)

As shown in Figure 4, heat pumps have increased in market share (relative to other heating systems) in the United States for approximately the past 12 years, maintaining close to $40 \%$ of the national market over the past couple of years. A closer look at how heat pumps fair in the four individual census regions, however, shows mixed performance. As of 2012, heat pumps accounted for well over half of all heating systems installed in new single-family houses in the South, with significant boosts beginning around 2002 (U.S. Census Bureau, 2013). A U.S. population shift from colder to warmer climates (U.S. EIA, 2013), like the South, is believed to have an overall positive impact on heat pump sales given that region's favorable market for ASHPs as noted above. More houses built in this region likely means more heat pumps installed over time, and this population shift is anticipated to continue through 2030.

The Midwest region experienced a similar boost in shipments starting in 2002, capturing approximately $20 \%$ of the market by $2009-2010$, but has started to tail off in recent years. The West demonstrated its highest market share back in the early 1980s, but has since lost ground to competing technologies. Finally, the Northeast has experienced rather steady, although minimal, market share at roughly $10 \%$ (U.S. Census Bureau, 2013). 


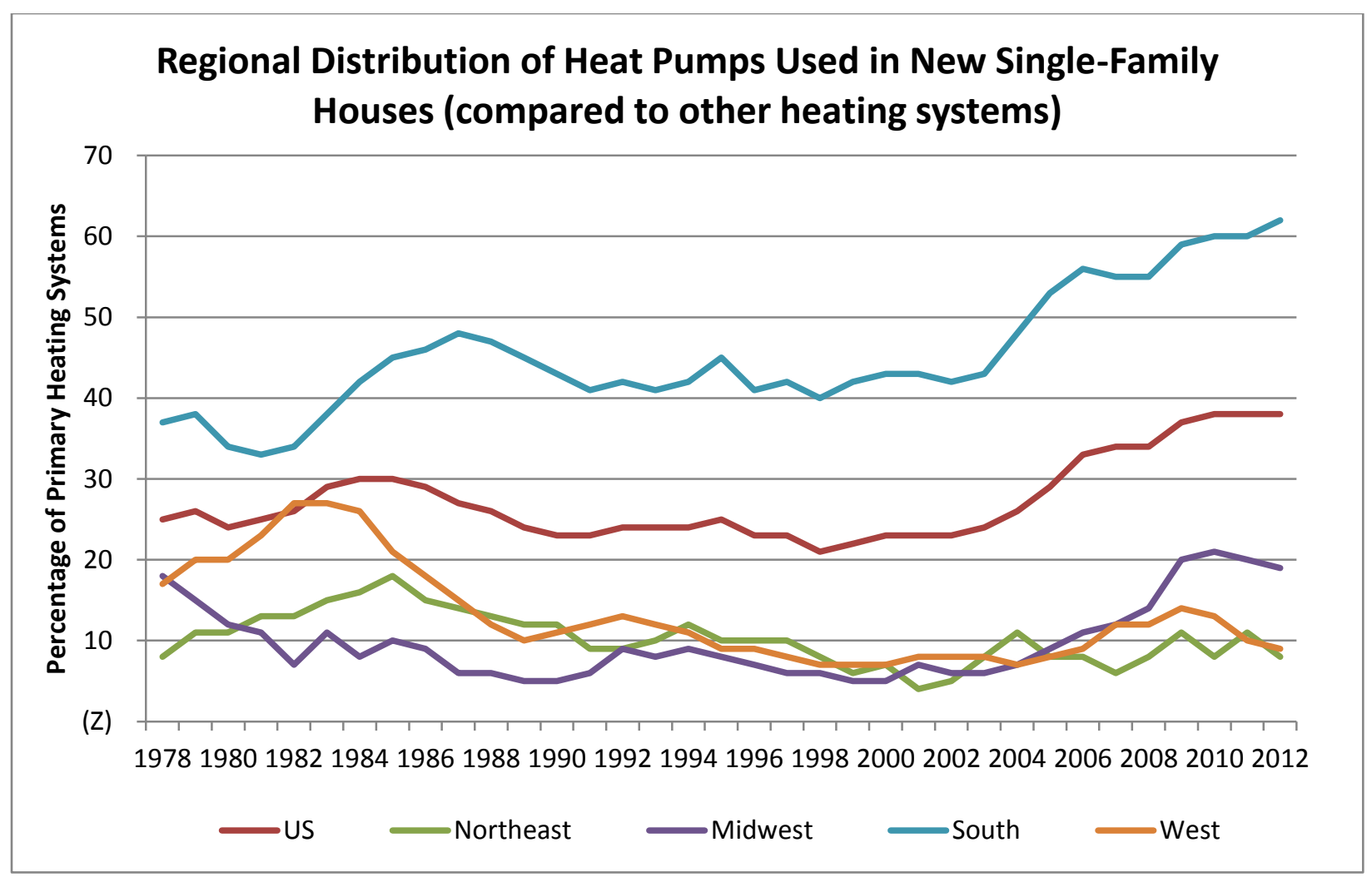

Figure 4: Heat pump market share by region

The introduction of cold climate heat pumps (CCHP) and other improved technologies is expected to aid in the expansion of the heat pump market beyond the Sunbelt areas into the colder regions traditionally dominated by gas furnaces. The Residential Energy Consumption Survey (RECS) heating stock data in 2001, 2005, and 2009 for cold / very cold regions of the country shows that gas furnaces are slowly losing traction within the market and that electric furnaces and HPs are gaining momentum, showing promise for the future penetration of cold climate heat pumps. Furthermore, regional standards for gas furnaces are expected to become stricter in the near future, requiring an increase in the minimum efficiency to an annual fuel utilization efficiency (AFUE) rating of $90 \%$ in the cold / very cold (northern) part of the country, which will increase the initial equipment cost, potentially leading to new trends in heating equipment (Khowailed et al., 2011).

\section{LITERATURE REVIEW}

A review of previous and current literature was performed to examine the results of earlier cold climate specific ASHP R\&D activities and to identify candidate heat pump technology advances that could achieve sufficient heating capacities and desirable efficiencies while operating at low outdoor temperatures. Ultimately, the goal of the literature review is to highlight the development status of technologies that could lead to greater heating seasonal efficiency for heat pumps (particularly ASHPs) in colder climate locations. Much of the current literature review summarized in this section is taken from a Master's Thesis by Caskey (2013). 


\subsection{Pre-1990 cold climate heat pump R\&D in the United States}

Considerable research and development activity was begun in the U. S. in the late 1970's and early 1980's to improve the performance of ASHPs, resulting in higher efficiency and more reliable products for northern U. S. applications (Groff and Reedy, 1978; Groff et al., 1978, Groff et al., 1979; Bullock et al., 1980). A great deal was learned about the technology needs to enable heat pumps to become more attractive for colder climate applications. In intervening years, advanced heat pump designs have been pursued (and some have been brought to the market) that incorporate design concepts or features for improved cold climate performance (see for instance Hadley et al., 2006). While many of these improved heat pump designs have been technically successful, market opportunities were limited due to the continuing relatively low cost of fossil fuels vs. electricity and to the higher initial cost of these products and systems.

In the mid-1970s electric utility companies were motivated to sponsor research into alternative electrically operated heating products as an alternative to direct electric heaters and gas or oil furnaces. Notable programs launched during this period were undertaken by EPRI, EESERCO (a consortium of Northeastern U.S. utilities) and Niagara Power Corporation (now National Grid). Westinghouse's research group was awarded a contract by EPRI to identify heat pump design concepts (including in combination with solar energy utilization) that would be effective in the colder climates. EESERCO and Niagara Mohawk sponsored similar projects that were focused on more practical design solutions (i.e. that could be carried to actual product development). These latter studies (as undertaken by the Carrier Corporation Research Division), included field monitoring of ASHPs in residences in four northern U. S. cities with varying climate conditions - Boston, MA; Syracuse, NY; Minneapolis, MN; and Seattle, WA. All of these locations experienced at least $2800{ }^{\circ} \mathrm{C}$-days $\left(5,000{ }^{\circ} \mathrm{F}\right.$-days) of heating. In addition a detailed seasonal performance (SPF) simulation model was developed, calibrated using data from the field monitoring, and used for parametric studies (Groff and Reedy, 1978; Groff et al., 1978). The heat pumps used in the field studies were single-speed ASHPs typical of those available in the 1960s and 1970's, applied to residences and one commercial building - see Figure 5 for two examples.
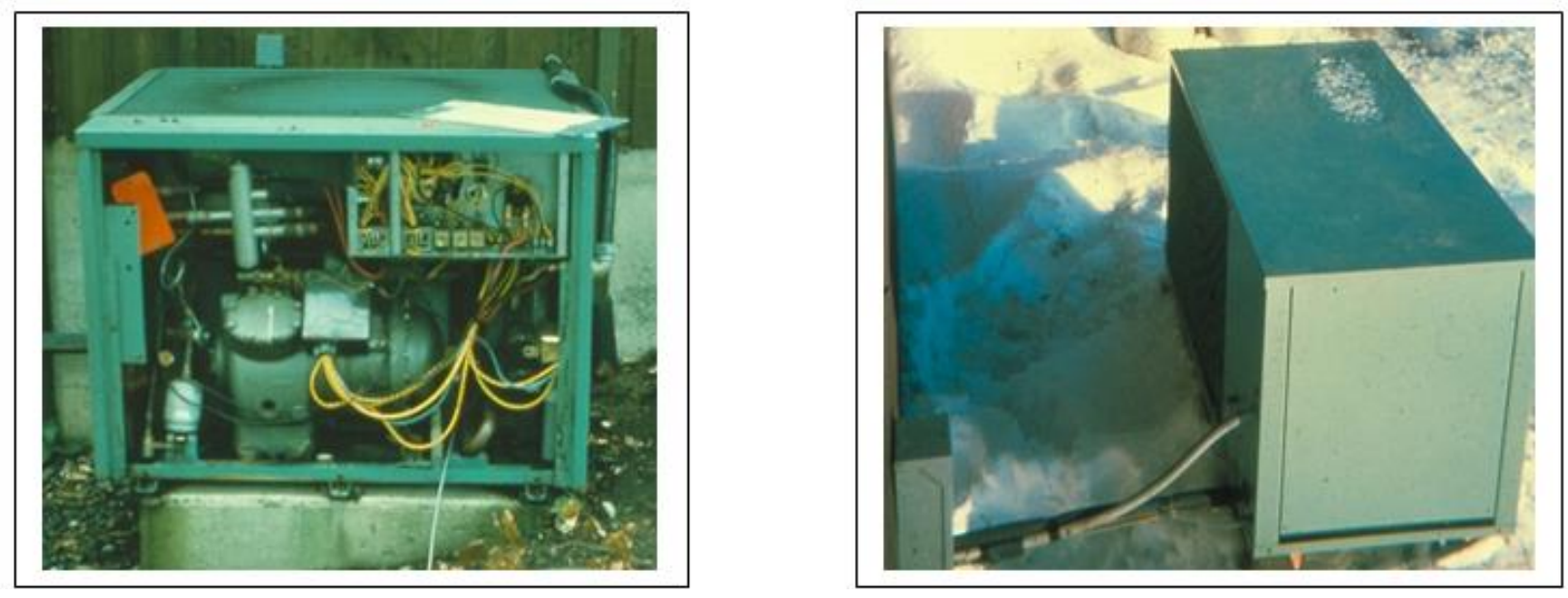

Figure 5: Sample outdoor sections of heat pumps field tested from 1976-1978: left, ca 1960's unit installed in Seattle residence (note semi hermetic compressor); right, ca 1970's unit originally installed in Minneapolis residence (note - unit was undersized) 
Field measured SPFs for the tested heat pumps ranged from 1.20 in the coldest location (Minneapolis), to 1.5-1.6 (Boston and Syracuse), to 2.2 in the mild Seattle location. These values were impacted by the fact that the 1976 winter experienced much lower outdoor temperatures than average for the three coldest locations. Using the calibrated SPF model it was projected that for average weather at these locations, the SPFs would have been slightly higher, ranging from about 1.3 to 2.3 (Groff and Reedy, 1978; Groff et al., 1978). The heat pump tested in Minneapolis was undersized for the house and location, so a subsequent year of testing was undertaken using a larger and more efficient ASHP (30\% increased capacity and $19 \%$ higher $\mathrm{COP}$ at the $8^{\circ} \mathrm{C}$ (or $47^{\circ} \mathrm{F}$ ) rating point). The field measured heating season results showed an increase in SPF of 24\% (1.49 vs. 1.2 the previous year) (Groff et al., 1979). This illustrates the inherent advantage of increasing the heat pump size (heating capacity) for improving SPF in colder locations.

Bullock et al. (1980) described a more detailed heat pump sizing study based on ranges of heat pump capacity levels, house load (e. g. thermal envelope) characteristics, climatic conditions (e.g. locations) and economic factors (operating and maintenance costs, fuel costs, and fuel cost escalation rates). A metric called the size ratio (SR) was defined as shown in Figure 6 to characterize the heating capacity of a heat pump relative to its heating load at the standard rating temperature of $8.33^{\circ} \mathrm{C}\left(47^{\circ} \mathrm{F}\right)$. Four local climate levels were considered, denoted as $A-D$ with $A$ the mildest and $D$ the most severe (highest heating degree-days). Three house thermal envelope levels were considered -1 being the most insulated, least infiltration (with lowest heating requirement) and 3 the lowest (with highest heating requirement. Three different fuel cost escalation rate $\left(\mathrm{I}_{\mathrm{ESC}}\right)$ assumptions were considered as well $-0-10 \%$. Figures 7 and 8 illustrate typical results generated for a mild and severe climate, respectively. It can be seen that for the more severe climate (Figure 8), the SR is much more dependent on the range of house load levels and fuel cost factors. Generally, higher values for IESC favor larger SR values. More heavily insulated h ( aka house level 3) also tend to favor higher SR values - however the absolute heat pump size for more efficient homes would generally be smaller due to the smaller absolute heating requirement. Figure 9 illustrates the range of optimum SR values vs. heating degree days. For this figure, the "upper" boundary would be typical for better insulated homes with a high $\mathrm{I}_{\mathrm{ESC}}$ assumption. Conversely, the "lower" boundary would pertain to less insulated dwellings and a low IESC assumption. 


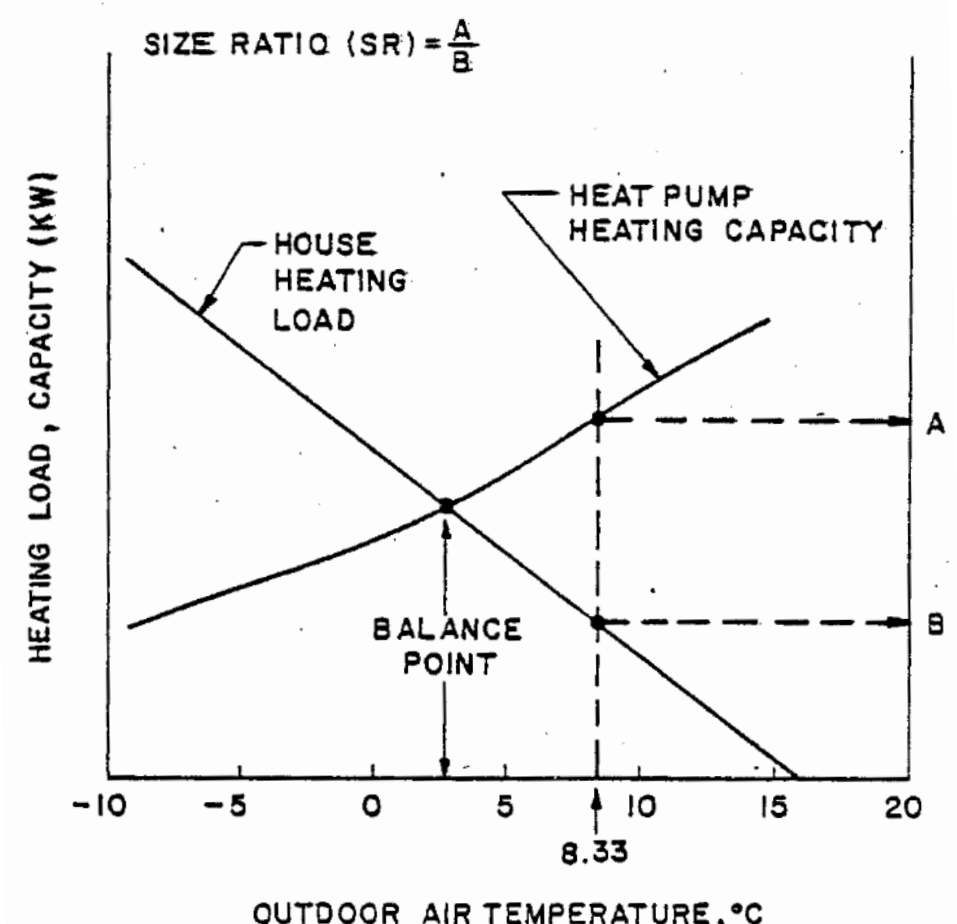

Figure 6: Size Ratio (SR) definition (from Bullock et al., 1980)

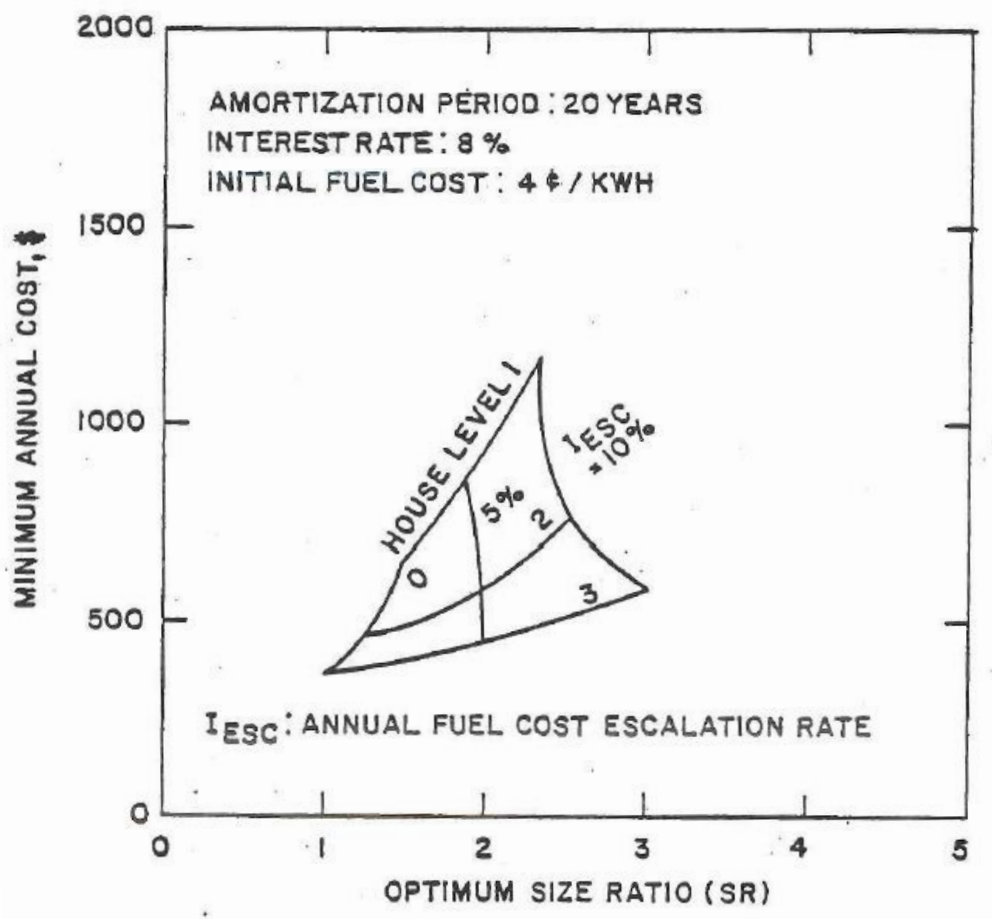

Figure 7: Heat pump minimum annual cost vs. Size Ratio for mild location - climate A (from Bullock et al., 1980) 


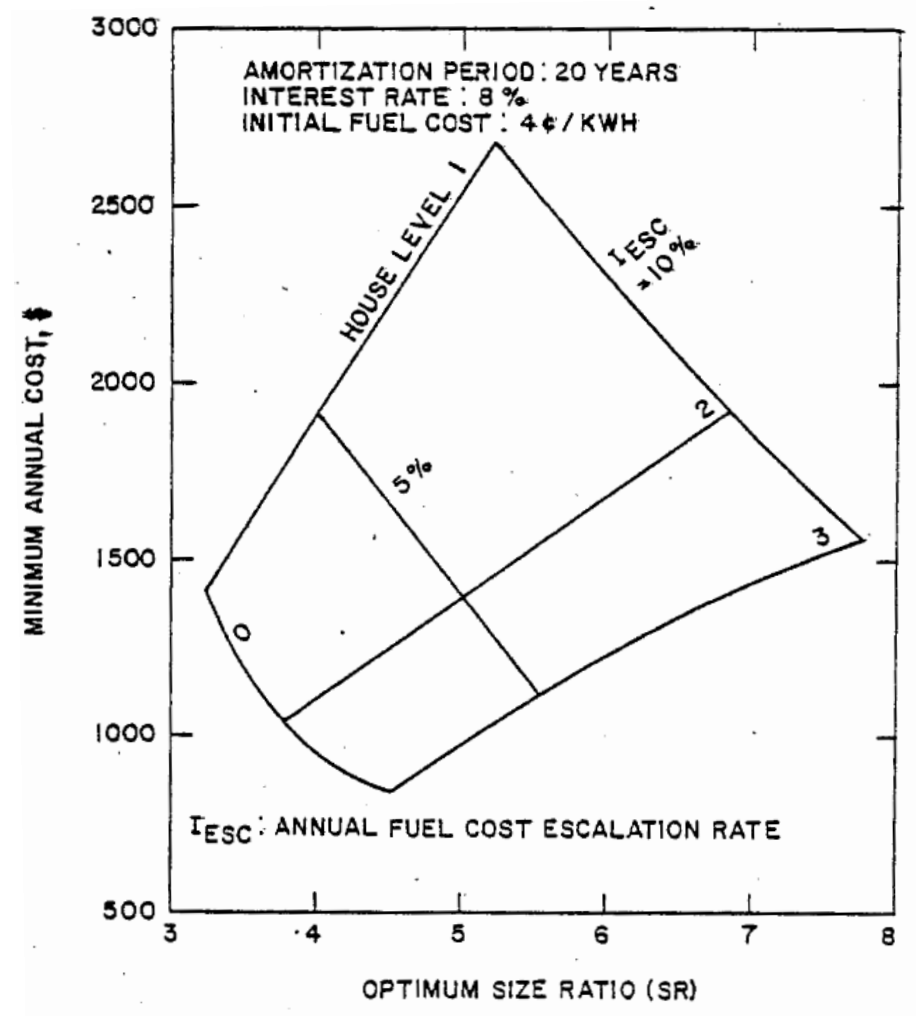

Figure 8: Heat pump minimum annual cost vs. Size Ratio for severe location - climate D (from Bullock et al., 1980)

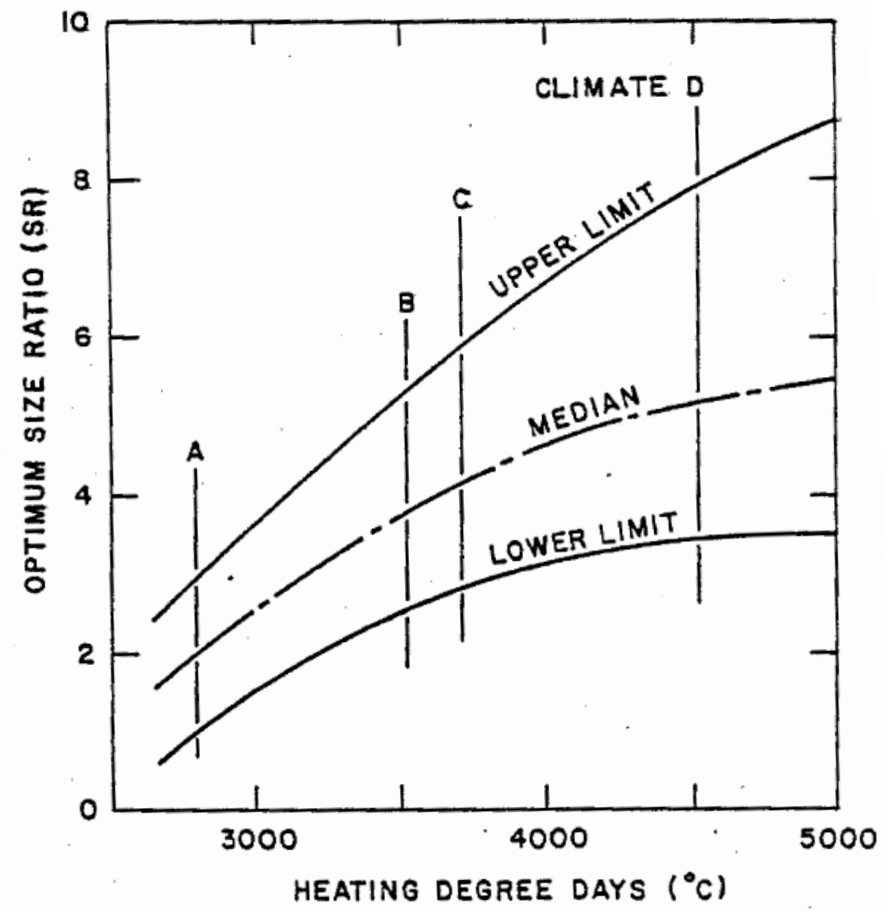

Figure 9: Optimum Size Ratio (SR) vs. heating degree-days (from Bullock et al., 1980) 
It is important to note, as pointed out in Bullock et al. (1980), the curves in Figure 9 are not "general" but are tied to the particular set of assumptions about the house and cost parameters used. Also note that the foregoing information was developed for single-speed ASHP equipment of circa 1970 design, far less efficient than current models being marketed in the United States.

From the field testing and computer studies, new product designs were formulated by the Carrier Research group, leading to prototype models that were also tested in the field over the following years. Among the most important features for good cold climate performance included in the prototypes were demand defrost systems, application of properly sized receivers, and minimization of reversing valve thermal losses.

In parallel with the field studies above, the Carrier group also analytically examined the energy savings potential of thermostat night set back control. Results indicated that use of night set back with heat pumps in colder climates could yield modest improvements in heating SPF. But careful system control (especially of the electric supplemental heaters) would be critical. The study concluded that night set back was not recommended for existing heat pump technology at the time (see Bullock, 1978).

The Carrier group was also invited to join Électricité de France (EdF) in a program to investigate electric ASHPs (both air-to-air and air-to-water types) for heating in the French climates. Field tests were conducted on several residences with various existing heating system types and for two large commercial buildings. These studies were reported in papers by Groff et al. (1984) and by Groff and Moreau (1983). From these studies, two prototypes with functions and features for improved cold climate performance were designed and fabricated. These units were installed in U.S. and French homes and were monitored to determine actual performance. A number of the design elements developed for these prototypes were utilized in later Carrier products including a 3 piece heat pump for cold climate applications (pictured in Figure 10) that incorporated an outdoor fan-coil unit, an indoor fan-coil unit and an indoor compressor box (to enable capture of compressor heat to the indoor environment).

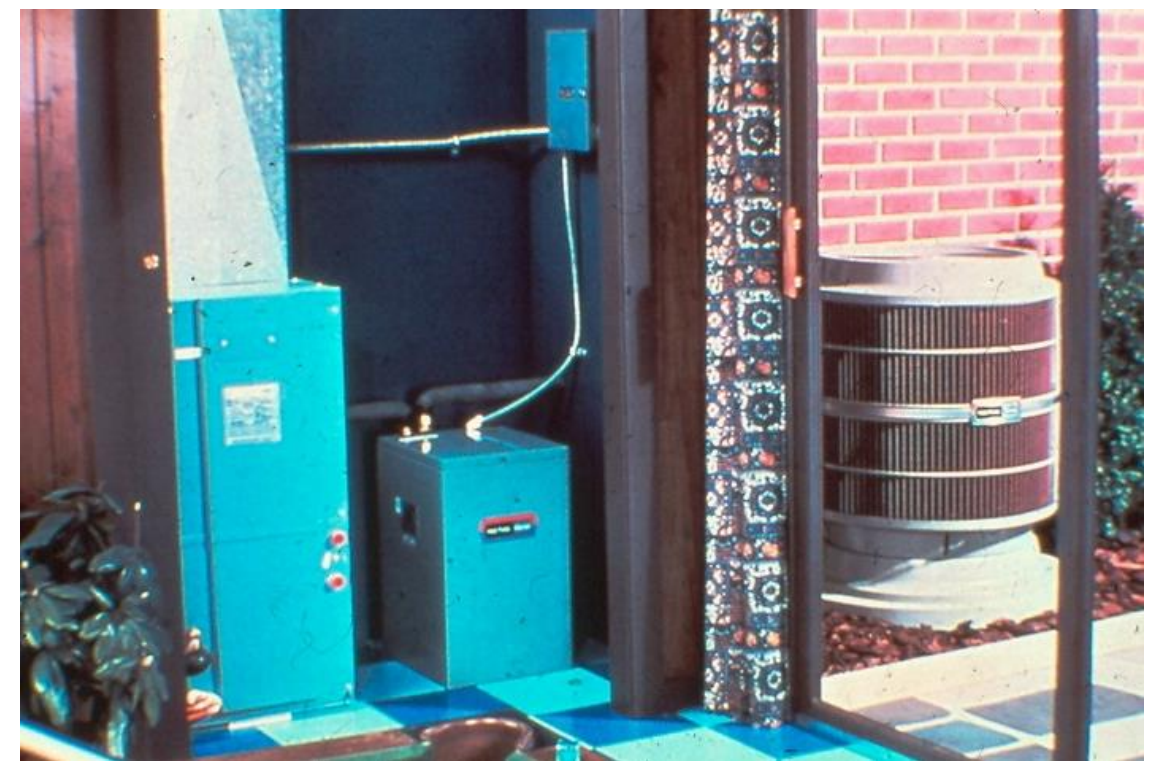

Figure 10: Early 1980's 3-piece ASHP design for northern climate applications 
More advanced designs incorporating various approaches for capacity modulation (multiple compressors, multiple speed or displacement compressors, inverter-driven system technology, etc.) can be and have been developed (Lannus, 1993; Hadley et al., 2006) with varying degrees of market success. Variable capacity systems also have an advantage in that they can operate at lower capacity or lower compressor speed in the cooling season, thus avoiding cooling performance penalties that typically accrue from oversizing. Modifications to the vapor compression cycle itself (incorporation of ejectors, multiple stage cycles, etc.) can also be used to boost low temperature capacity and efficiency. The following section discusses some of the more recent developments.

\subsection{Recent U. S. R\&D Efforts and Developments - Low Outdoor Temperature Air- Source Heat Pumps}

\subsubsection{Multi-stage compressor system investigation}

A conference paper by Bertsch et al. (2006) investigated in detail three heat pump technologies for use in cold climates. The authors first identified the four principle problem areas faced by ASHPs when operating at low outdoor temperatures. The first issue is a lack of heating capacity caused by lower refrigerant flow rates at the low temperatures when the heating load is the largest - which leads to significant need for a backup heating source, usually provided by electric resistance heaters, to supplement the heat pump output. The second issue is that the discharge temperature of the compressor reaches high levels due to the low suction pressures and high compressor pressure ratio experienced at low ambient temperature operation. The third issue is that the heat pump COP decreases quickly under low outdoor temperature operation. The last main problem involves sizing the heat pump capacity. If the heat pump capacity is sized to meet house design heating loads at a very low outdoor temperature, this leads to oversizing for cooling, resulting in frequent cycling and degraded cooling seasonal performance.

Six different heat pump technologies were identified that have the potential to solve some of these issues in varying degrees. Table 2 provides a side-by-side comparison between these six technologies and a conventional heat pump and shows the number of heating modes, efficiency, heat output and discharge temperature of each technology.

Table 2: Comparing different heat pump technologies to a single-stage baseline (Bertsch et al., 2006)

\begin{tabular}{|c|c|c|c|c|c|c|}
\hline$\#$ & Concept & $\begin{array}{c}\text { Preferred } \\
\text { Compressor }^{*}\end{array}$ & $\begin{array}{c}\text { Number heat } \\
\text { output steps }\end{array}$ & $\begin{array}{c}\text { Relative } \\
\text { Efficiency }\end{array}$ & $\begin{array}{c}\text { Relative } \\
\text { Heat output }\end{array}$ & $\begin{array}{c}\text { Discharge } \\
\text { temperature }\end{array}$ \\
\hline 1 & 1-stage cycle & LT & 1 & $100 \%$ & $100 \%$ & High \\
\hline \multirow{2}{*}{2} & \multirow{2}{*}{ 2-stage w. intercooler } & 2-stage & 1 & $130 \%$ & $100 \%$ & Acceptable \\
\cline { 3 - 7 } & \multirow{2}{*}{3} & 2-stage w. Recip, Rot & 3 & $130 \%$ & $140 \%$ & Acceptable \\
\hline 4 & Cascade cycle & 2-stage & 1 & $130 \%$ & $100 \%$ & Low \\
\cline { 3 - 7 } & Refrigerant injection & Sc, Screw & 2 & $130 \%$ & $150 \%$ & Low \\
\hline 6 & Oil cooling & Recip, Rot & 1 & Comparable & $115 \%$ & Low \\
\hline 7 & Mechanical subcooling & LT + Sc & 2 & $110 \%$ & $120 \%$ & High \\
\hline
\end{tabular}

*) Sc...Scroll, Recip...Reciprocating, Rot...Rotary, LT...Low temperature 
Three of these technology options were selected for detailed comparison - the two-stage using an intercooler, the two-stage using an economizer and the cascade cycle. It can be seen from Table 2 that these three technologies have the highest relative efficiency and relative heat output with low or acceptable discharge temperatures. The schematic for each of these three technologies is shown in Figure 11Figure 1.
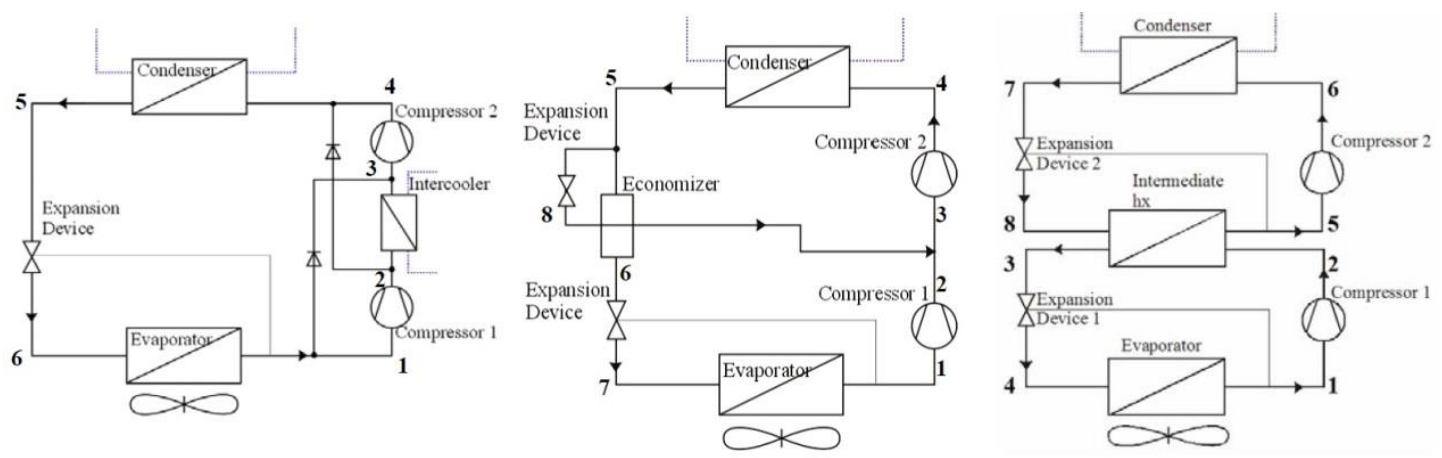

Figure 11: Heat pump schematic - Intercooler (Left) - Economizer (Middle) - Cascade (Right) (Bertsch et al., 2006)

System simulation models were created for each of the three technologies to simulate the heating capacity and performance for comparison. The supply temperature for each was fixed to $50^{\circ} \mathrm{C}\left(122^{\circ} \mathrm{F}\right)$. A plot of the COP versus outdoor temperature for each heat pump technology is shown in Figure 12 and is compared to a second law efficiency of 50\%. The intercooler and economizer cycles show similar performance at temperatures above $0^{\circ} \mathrm{C}\left(32^{\circ} \mathrm{F}\right)$ while the cascade cycle performs relatively better at colder temperatures. All cycles show COPs above 2 at the low outdoor temperatures indicating reasonably good efficiency during these extremes. 


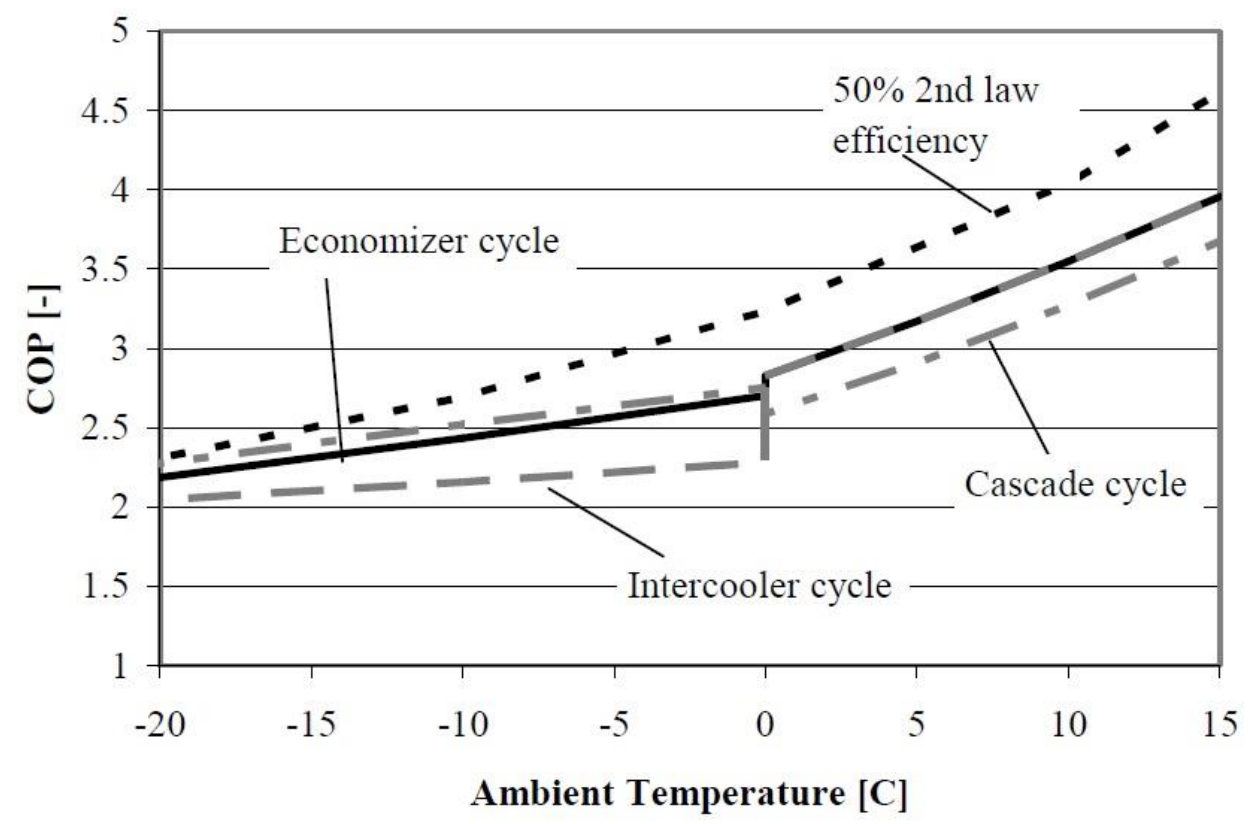

Figure 12: Comparison of the COP for the three technologies with a $50 \%$ second law efficiency (Bertsch et al., 2006)

The heating capacity compared to a linear heating demand of a building is plotted versus the outdoor temperature for all three technologies as shown in Figure 13. All three cycles have similar capacities at the low ambient temperatures. The only noticeable difference between these technologies is at the warmer ambient temperatures. The cascade cycle COP is considerably lower than that of the economizer and intercooler cycles, and this is most likely due to the sizing selected for the high stage cycle. Bertsch et al. assumed the cascade cycle has an additional outdoor heat exchanger to allow for the high side cycle to operate without the low side cycle. Overall, all three cycles are predicted to be able to satisfy the heating load. The conclusion made from these results and the equipment required is that the two-stage economizer cycle would be the best choice for an ASHP in colder climates. 


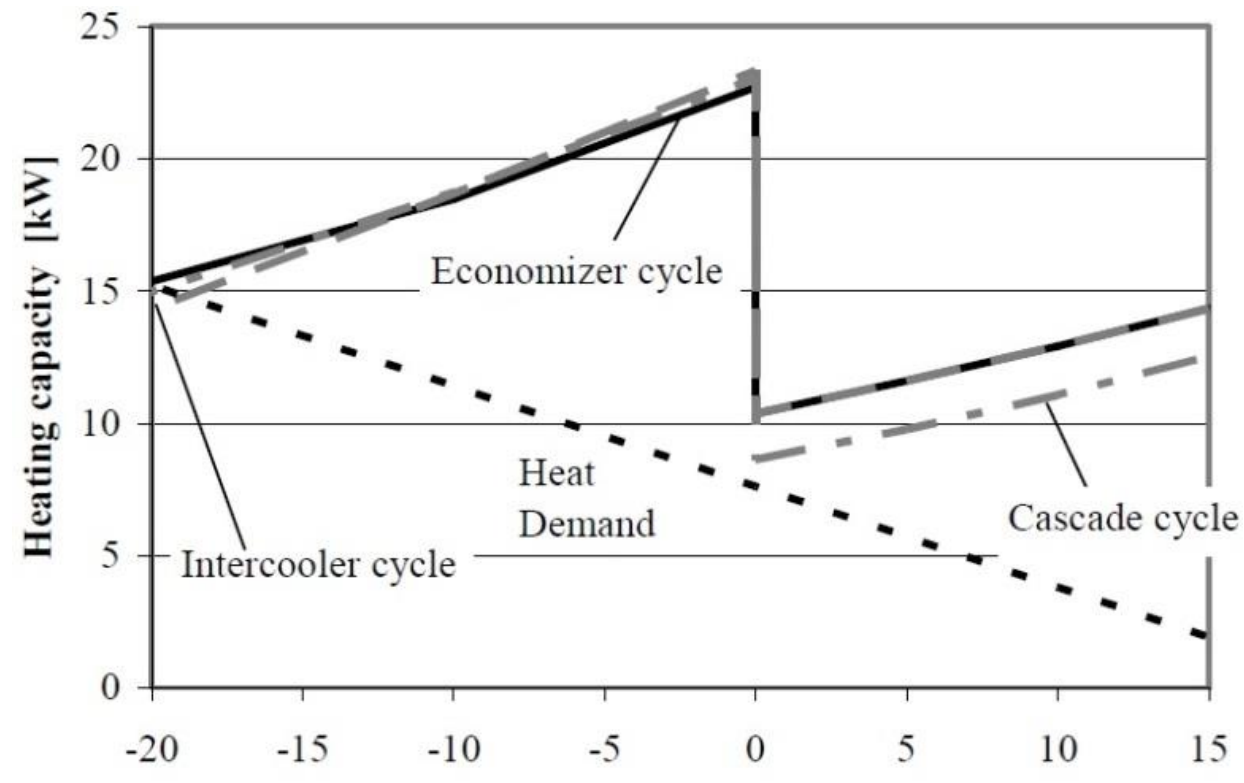

Ambient Temperature [C]

Figure 13: Comparison of the heating capacity for the three technologies (Bertsch et al., 2006)

\subsubsection{Vapor Injection (VI) Heat Pump}

Heat pumps with compressor vapor injection (VI) can be classified into two fundamental configurations. One utilizes a flash tank also known as an open economizer and the other uses a heat exchanger economizer or closed economizer. Figure 14 shows a schematic of each system. The flash tank cycle uses an expansion valve before a fixed volume tank to separate the liquid and vapor refrigerant at an intermediate pressure. The saturated vapor is drawn from the top of the tank and enters an injection port on the compressor. The saturated liquid is expanded further to the evaporation pressure. For the economizing heat exchanger cycle, the subcooled liquid leaving the condenser is separated into two streams; one is expanded to an intermediate pressure and heated by subcooling the other refrigerant stream through the heat exchanger. The superheated refrigerant enters the injection port on the compressor. If the phase separation process in the flash tank was perfect and the superheat entering the injection port of the compressor from the economizer heat exchanger was zero, the ideal cycles of both systems would be thermodynamically identical (Wang et al., 2009). 


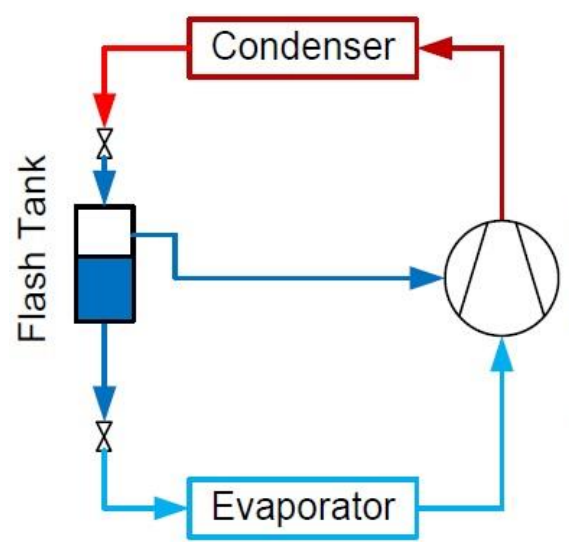

(a)

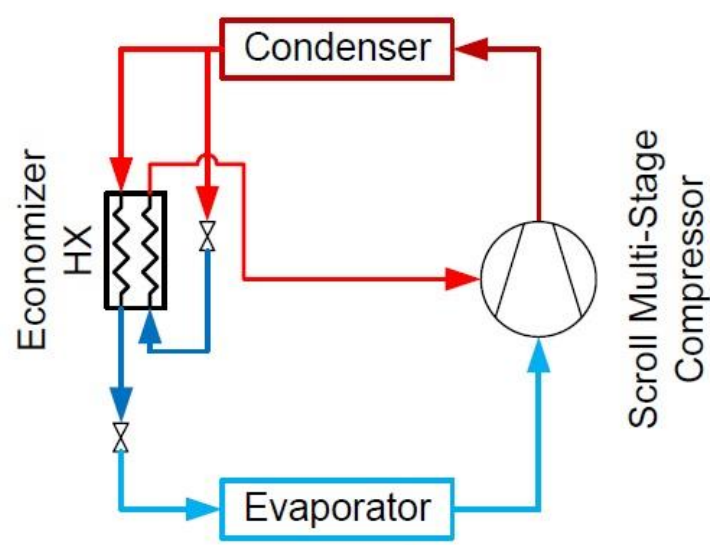

(b)

Figure 14: Schematic of two VI cycles with (a) flash tank (b) economizer heat exchanger (Abdelaziz et al., 2011)

These systems create a multi-stage compression process within one compressor by mixing the superheated vapor in the compressor with saturated or a smaller degree of superheated vapor. As the number of injection ports is increased to approach continuous injection, the compression process will follow the refrigerant vapor saturation curve. One model predicts that continuous injection will improve the system COP between $18 \%$ and $51 \%$ for common air-conditioning and refrigeration applications, where higher temperature lift cycles benefit most significantly (Mathison et al., 2011). Abdelaziz and Shen (2012) conducted an optimization analysis of the two cycles in Figure 14. Optimizations were conducted to 1) minimize heat exchanger (HX) area subject to prescribed capacity and COP at rating conditions $\left(47^{\circ} \mathrm{F}\right.$ or $\left.8.3^{\circ} \mathrm{C}\right)$ followed by 2$)$ analysis to maximize system efficiency subject to a minimum capacity constraint at a low temperature operation condition $\left(-15^{\circ} \mathrm{F}\right.$ or $\left.-26.1^{\circ} \mathrm{C}\right)$. Their result suggested that the flash tank cycle of Figure 14(a) offers both lower system HX sizes and better performance at the low ambient condition.

Experimental results on an $11 \mathrm{~kW}$ R410a heat pump with flash tank VI showed about $30 \%$ heating capacity improvement with $20 \%$ COP gain at the ambient temperature of $-17.8^{\circ} \mathrm{C}\left(0^{\circ} \mathrm{F}\right)$ when compared to a conventional system having the same compressor displacement volume (Wang et al., 2009). The system capacity for both heating and cooling compared to the conventional system is shown in Figure 15 as a function of the outdoor temperature. The system heating and cooling capacity increases when vapor injection is used compared to the conventional system. 


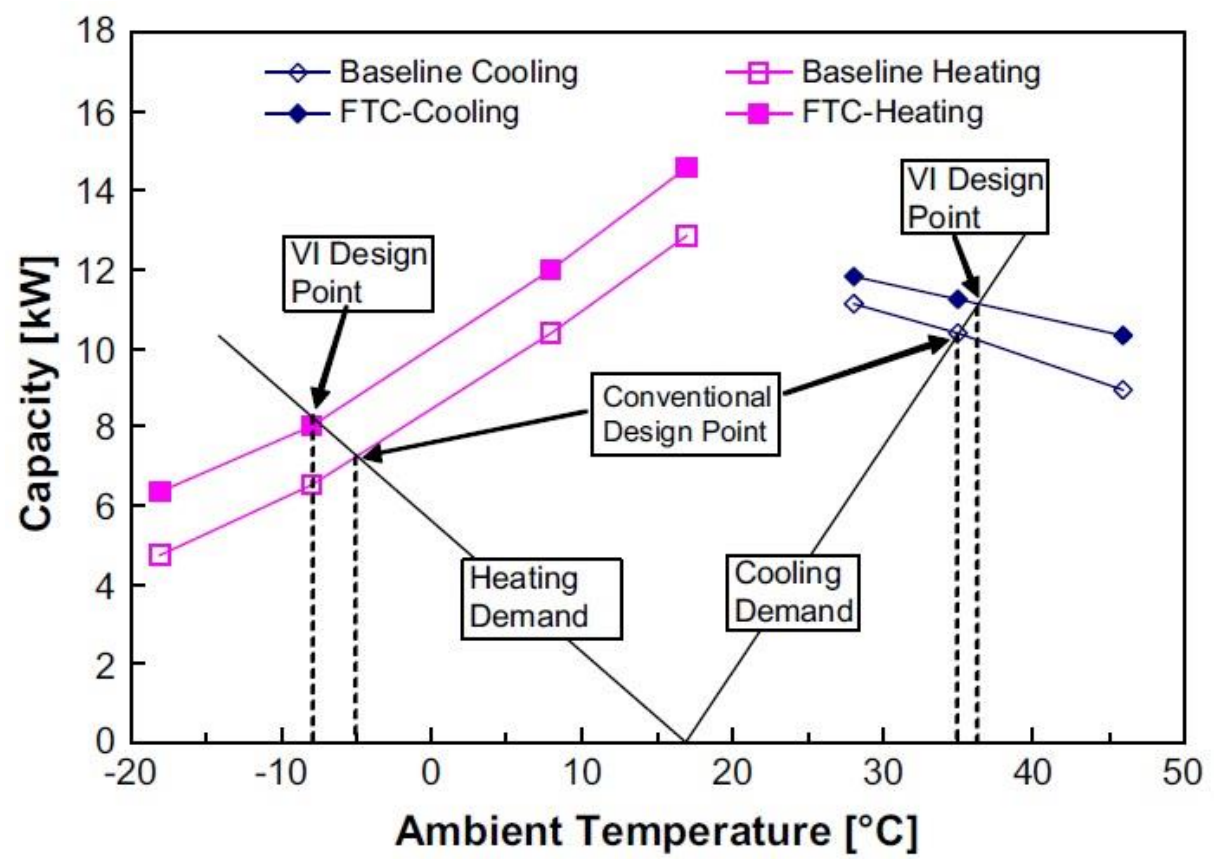

Figure 15: Flash tank VI cycle (FTC) compared to conventional (baseline) heat pump (Wang et al., 2009)

When comparing the two types of $\mathrm{VI}$ cycles, experimental results have shown the flash tank cycle to have a heating capacity and COP of $10.5 \%$ and $4.3 \%$ higher, respectively, than the economizing heat exchanger cycle (Ma and Zhao, 2008). A literature review of VI cycles concluded that the flash tank cycle is more favorable in terms of the performance improvement and cost while the economizing heat exchanger has the advantage of wider $\mathrm{VI}$ operating range (Xu et al., 2011). For R-410A, there have been some experimental and theoretical investigations of the air-source, vapor injection heat pump, but additional experimental results are needed to fully understand the various VI cycle options (Rohm et al., 2011).

VI cycle concepts utilizing multi-port compressors (one implementation of multi-stage VI compression) have also been investigated (Song, 2013; Ramaraj, 2012; Mathison et al., 2011). Figure 16 illustrates the cycle concept (a) and an example implementation in a scroll compressor (b). Previous theoretical and experimental work has shown that economizing holds significant potential to improve the performance of vapor compression equipment. Mathison et al. (2011) predicted that the maximum performance improvement with economizing can be achieved by continuously injecting two-phase refrigerant to maintain a saturated vapor state in the compressor. For an R-410A cycle evaporating at $5^{\circ} \mathrm{C}$ and condensing at $40^{\circ} \mathrm{C}$, the cycle model predicts that economizing will improve the COP by approximately $18 \%$ in this limiting case. The benefits are even greater for a larger temperature lift application, such as a cold climate heat pumps; the model predicts that economizing can provide up to a $51 \%$ improvement in COP for a cycle using R-404A with an evaporation temperature of $-30^{\circ} \mathrm{C}$ and a condensing temperature of $40^{\circ} \mathrm{C}$. However, continuously injecting refrigerant is not only beyond the capabilities of current compressors, but also requires the development of equipment to continuously supply refrigerant to the compressor at the desired pressure and quality. In addition, injecting a two-phase mixture introduces the possibility for damage to the compressor if the evaporation process within the compressor is not well-understood. 
Mathison (2011) demonstrated that using a finite number of injection ports and saturated vapor in place of a two-phase mixture provides a practical means for approaching the limiting cycle performance. For the R-410A cycle evaporating at $5^{\circ} \mathrm{C}$ and condensing at $40^{\circ} \mathrm{C}$, the model predicted that injecting saturated vapor through three ports will provide a $12 \%$ improvement in COP, which is approximately $69 \%$ of the maximum benefit provided by economizing with continuous injection of two-phase refrigerant. Therefore, the development of the economized cycle currently focuses on using saturated vapor injection with two or three ports.
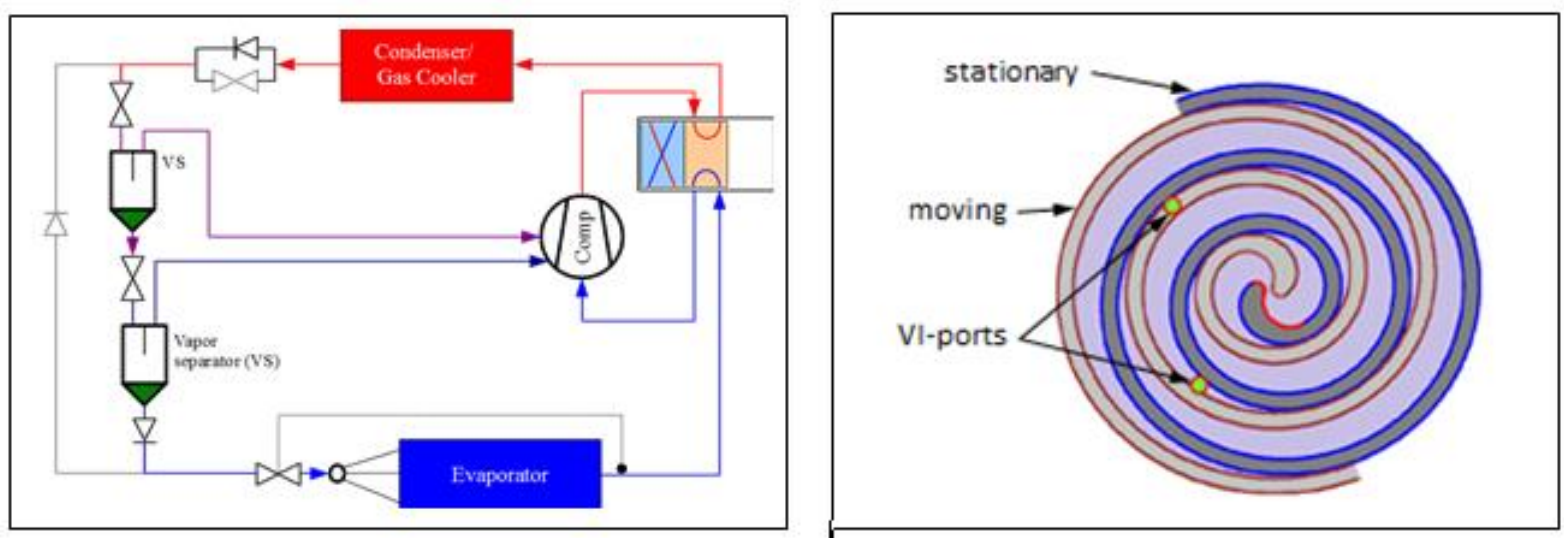

Figure 16: Multi-port VI compressor concept

\subsubsection{Two-Stage ASHPs with economizing}

The only difference between a two-stage economizer (see schematic in Figure 11 (middle)) and VI cycle is two individual compressors are used with a mixing chamber in between instead of directly injecting vapor into a compressor chamber of the compressor. By compressing the refrigerant in stages, a second-law-based thermodynamic analysis shows the increase in irreversible losses at high-temperature differences can be minimized. A two-stage R-134a refrigeration system operating at $-30^{\circ} \mathrm{C}$ evaporating and $60^{\circ} \mathrm{C}$ condensing has a $24 \%$ improvement in performance compared to a single-stage system (Zubair et al., 1996). Analysis on a cascade system highlights the reduction of entropy generation when compressing in stages. Going from 1 to 2 stages reduced the superheat losses significantly from $94 \mathrm{~kJ} / \mathrm{K}-\mathrm{hr}$ to $0.106 \mathrm{~kJ} / \mathrm{K}$-hr to reach an overall reduction of entropy generation by $78 \%$ (Ratts et al., 2000).

An R-134a two-stage heat pump with both an economizing heat exchanger and a flash tank was used for heating water from a waste energy source. In spite of the higher source temperatures used, the experimental results demonstrated the frequency control of the high-stage compressor to control the intermediate pressure resulted in an ability to improve the performance by as much as $5.2 \%$ as compared to the single-stage system without economizing under identical heat source conditions (Kwon et al., 2013). A normalized pressure is calculated using the three system pressures to identify the optimal operating point for fixed heat source temperatures. A plot of three different source temperatures for COP versus the normalized pressure is shown in Figure 17. 


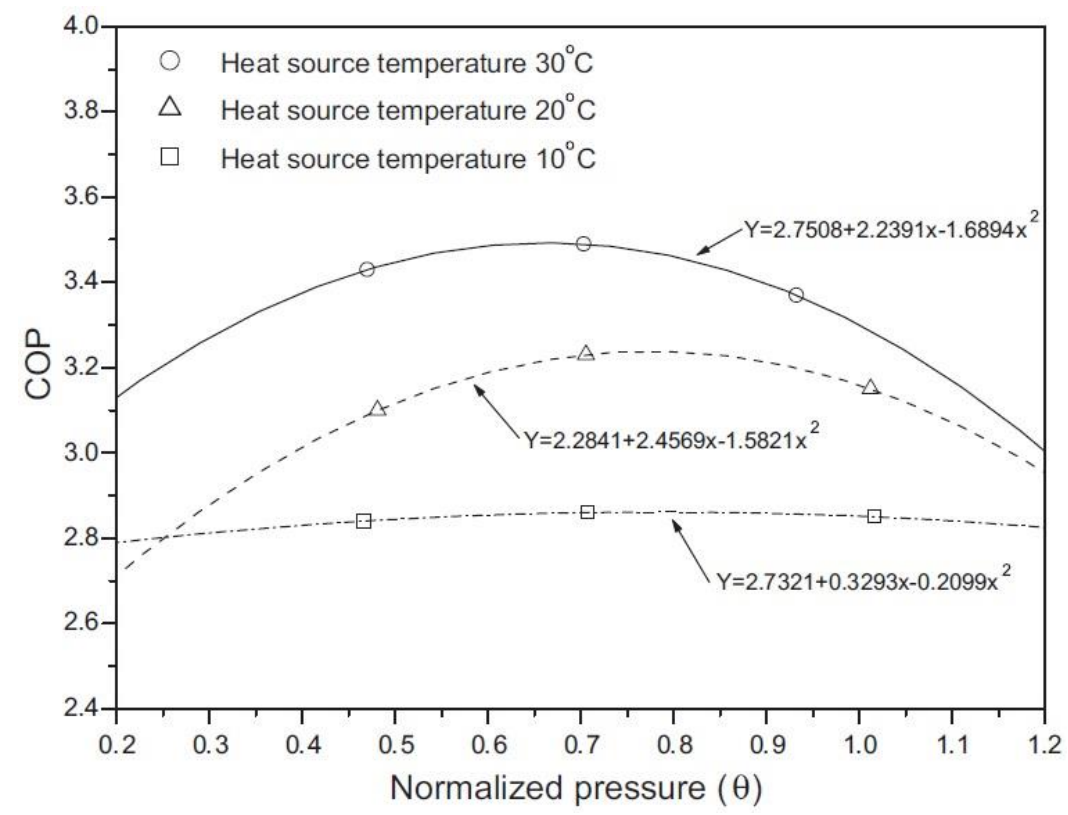

Figure 17: COP compared against the normalized pressure of two-stage heat pump (Kwon et al. 2013)

An R-410A two-stage heat pump with an economizing heat exchanger was experimental tested down to ambient temperatures of $-30^{\circ} \mathrm{C}\left(-22^{\circ} \mathrm{F}\right)$, achieving a heating capacity and COP of roughly $11 \mathrm{~kW}$ and 2.1 respectively (Bertsch et al., 2008). The plots of the experimental results compared to the simulation of the system heating capacity and COP are shown in Figure 18. The two-stage heat pump is shown to have much larger heating capacities than a conventional heat pump at low outdoor temperatures. The system could also be easily built from off-the-shelf components with little modifications which identifies the commercialization potential of a twostage heat pump with economizing heat exchanger.
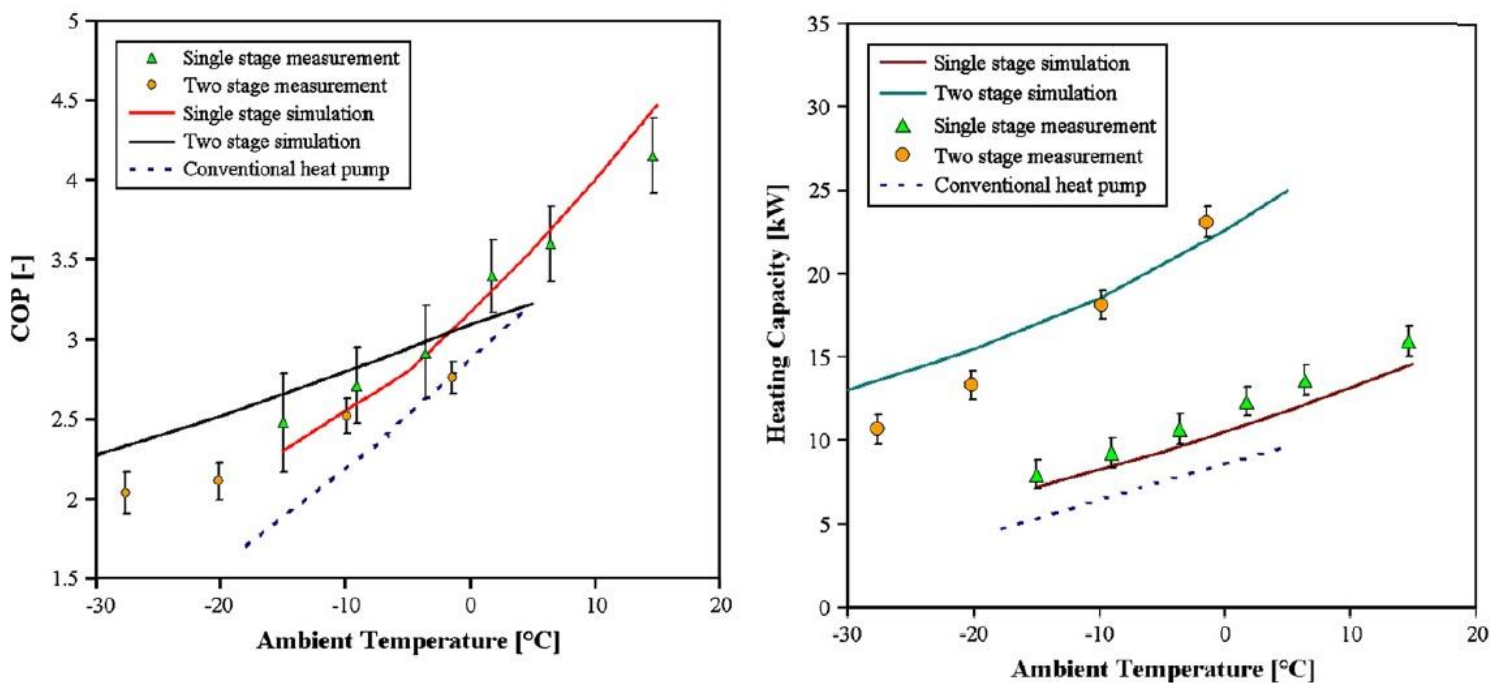

Figure 18: Experimental results of two-stage heat pump compared to simulation results; manufacturer's data was used to indicate performance of conventional HP (Bertsch et al. 2008) 


\subsubsection{Flooded compressor concept investigation}

The oil flooding concept utilizes oil injection into the compressor suction port(s) to absorb the heat of compression (reducing discharge temperature) and approach an isothermal compression process (Bell, 2011). Figure 19 illustrates a cycle schematic and $p$-h diagram of the concept. The addition of compressor flooding with regeneration in vapor compression systems results in a more isothermal compression process that can have a significant beneficial impact on system efficiency for large temperature lifts. For refrigerants with large pressure differences across the compressor, the use of a hydraulic expander can also help to recapture some of the work of compression of the flooding liquid. The engineering challenges in implementation of this technology are reasonable, which suggests that it could be applied readily in new construction. Analyses indicate this concept has both capacity and efficiency advantages over VI cycles for low-temperature applications (Bell et al., 2011). In particular, the injection of oil results in an increase in refrigerant mass flow rate and overall isentropic efficiency and a decrease in the compressor discharge temperature. The analyses conducted so far clearly suggest that designing an efficient scroll compressor with oil injection for application to a low-source-temperature ASHP application will be possible with respect to energy performance and manufacturability.
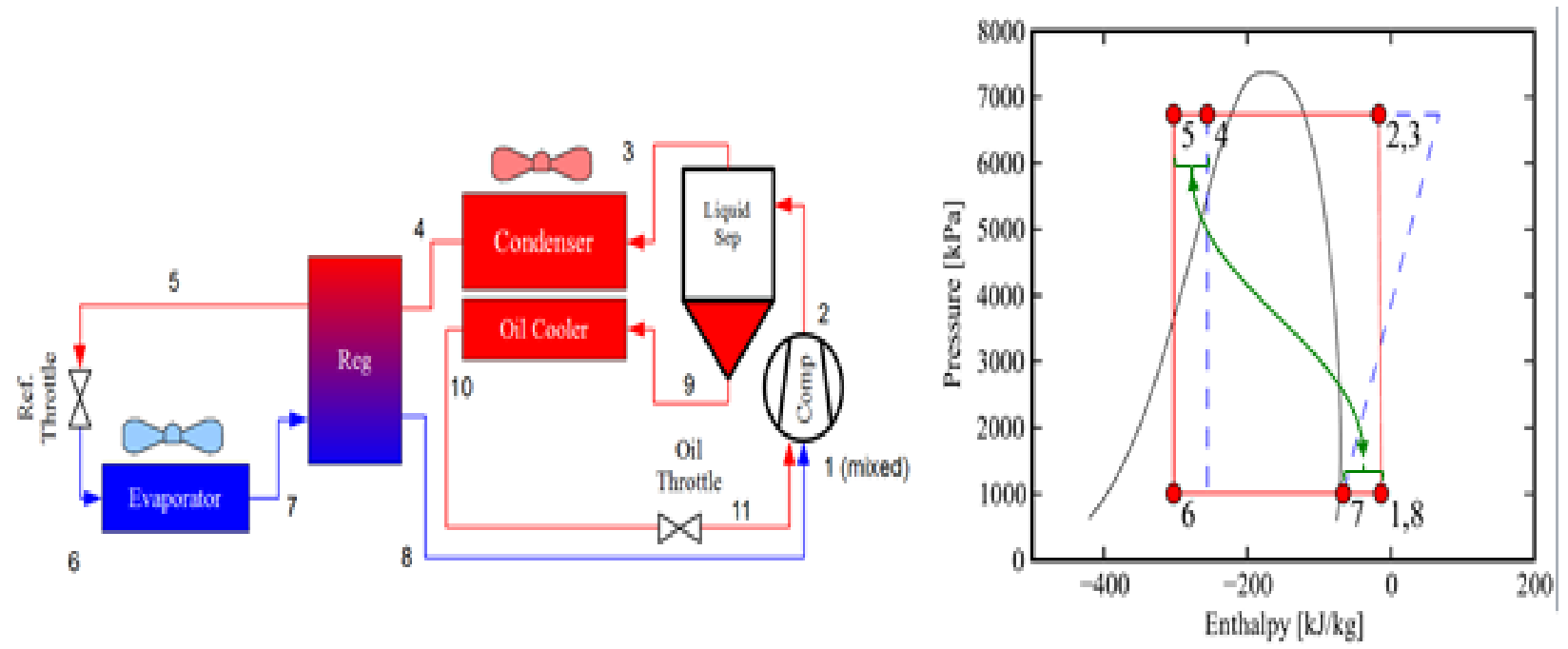

Figure 19: Schematic (left) and p-h cycle diagram (right) of flooded compressor cycle concept from Bell (2011)

\subsubsection{Cold climate field tests}

A field test was performed in several northern U. S. locations on a commercially available, multicapacity ASHP (Hadley et al., 2006) - Note - product no longer manufactured today. The manufacturer's data indicate a heating COP of 2.0 at $-23.3^{\circ} \mathrm{C}\left(-10^{\circ} \mathrm{F}\right)$ for the heat pump, as shown in Table 3. Additional heating COPs at different ambient temperatures are compared to those of a standard ASHP. 
Table 3: Manufacturer's heating COP data for field test ASHP designed for cold climates (CCHP) compared to a conventional air source heat pump (Std. ASHP) (Hadley et al., 2006)

\begin{tabular}{|c|c|c|c|c|c|c|c|c|}
\hline $\begin{array}{c}\text { Outdoor } \\
\text { Air Temp. }\end{array}$ & $\mathbf{- 2 0}^{\circ} \mathbf{F}$ & $\mathbf{- 1 0}^{\mathbf{}} \mathbf{F}$ & $\mathbf{0}^{\circ} \mathbf{F}$ & $\mathbf{1 0}^{\circ} \mathbf{F}$ & $\mathbf{2 0}^{\circ} \mathbf{F}$ & $\mathbf{3 0}^{\circ} \mathbf{F}$ & $\mathbf{4 0}^{\circ} \mathbf{F}$ & $\mathbf{5 0}^{\circ} \mathbf{F}$ \\
\hline CCHP & 1.9 & 2.0 & 2.2 & 2.2 & 2.5 & 2.8 & 3.1 & 3.3 \\
\hline Std. ASHP & na & na & 2.0 & 2.3 & 2.5 & 2.8 & 3.1 & 3.6 \\
\hline
\end{tabular}

Five of the advanced heat pumps were monitored over a winter in Oregon and Idaho. Six months after the installation, one heat pump had a compressor failure that required replacement. The reason for the failure was never determined. Another complication occurred where a booster compressor never engaged at another location. The measured average heating COP for outdoor temperatures between $-23.3^{\circ} \mathrm{C}$ and $-20.5^{\circ} \mathrm{C}\left(-10^{\circ} \mathrm{F}\right.$ and $\left.-5^{\circ} \mathrm{F}\right)$ was 1.2 , about $40 \%$ lower than the manufacturer's data indicated. The results for all five heat pumps at different temperature bins are shown in

Table 4. Overall the average field-measured COPs are considerably lower than the manufacturer's published values.

Table 4: Experimental results of the measured heating COP for all 5 locations (Hadley et al., 2006)

\begin{tabular}{|c|c|c|c|c|c|c|c|c|c|c|c|c|c|c|}
\hline $\begin{array}{l}\text { Outdoor } \\
\text { Temperature } \\
\text { Bin }\end{array}$ & $\begin{array}{c}-15^{\circ} \mathrm{F} \\
\text { to } \\
-10^{\circ} \mathrm{F}\end{array}$ & $\begin{array}{l}-10^{\circ} \mathrm{F} \\
\text { to } \\
-5^{\circ} \mathrm{F}\end{array}$ & $\begin{array}{l}-5^{\circ} \mathrm{F} \\
\text { to } \\
0^{\circ} \mathrm{F}\end{array}$ & $\begin{array}{l}0^{\circ} \mathrm{F} \\
\text { to } \\
5^{\circ} \mathrm{F}\end{array}$ & $\begin{array}{c}5^{\circ} \mathrm{F} \\
\text { to } \\
10^{\circ} \mathrm{F}\end{array}$ & $\begin{array}{c}10^{\circ} \mathrm{F} \\
\text { to } \\
15^{\circ} \mathrm{F}\end{array}$ & $\begin{array}{c}15^{\circ} \mathrm{F} \\
\text { to } \\
20^{\circ} \mathrm{F}\end{array}$ & $\begin{array}{l}20^{\circ} \mathrm{F} \\
\text { to } \\
25^{\circ} \mathrm{F}\end{array}$ & $\begin{array}{l}25^{\circ} \mathrm{F} \\
\text { to } \\
30^{\circ} \mathrm{F}\end{array}$ & $\begin{array}{c}30^{\circ} \mathrm{F} \\
\text { to } \\
35^{\circ} \mathrm{F}\end{array}$ & $\begin{array}{c}35^{\circ} \mathrm{F} \\
\text { to } \\
40^{\circ} \mathrm{F}\end{array}$ & $\begin{array}{l}40^{\circ} \mathrm{F} \\
\text { to } \\
45^{\circ} \mathrm{F}\end{array}$ & $\begin{array}{l}45^{\circ} \mathrm{F} \\
\text { to } \\
50^{\circ} \mathrm{F}\end{array}$ & $\begin{array}{l}50^{\circ} \mathrm{F} \\
\text { to } \\
55^{\circ} \mathrm{F}\end{array}$ \\
\hline Chiloquin & - & - & - & - & - & 1.3 & 1.5 & 1.6 & 1.6 & 1.7 & 1.9 & 1.9 & 1.8 & 2.0 \\
\hline Burley & - & - & 1.7 & 1.1 & 1.2 & 1.3 & 1.4 & 1.5 & 1.6 & 1.7 & 1.6 & 1.7 & 1.7 & 1.6 \\
\hline Paul & 1.5 & 1.5 & 1.6 & 1.6 & 1.6 & 1.6 & 1.6 & 1.7 & 1.8 & 1.9 & 2.0 & 2.1 & 2.1 & 1.9 \\
\hline Rigby & 1.3 & 1.2 & 1.2 & 1.3 & 1.3 & 1.3 & 1.4 & 1.4 & 1.5 & 1.6 & 1.6 & 1.6 & 1.5 & 1.4 \\
\hline Ashton & - & 1.0 & 1.4 & 1.3 & 1.2 & 1.2 & 1.2 & 1.3 & 1.3 & 1.3 & 1.4 & 1.4 & 2.0 & 1.7 \\
\hline Average & 1.4 & 1.2 & 1.5 & 1.3 & 1.3 & 1.4 & 1.4 & 1.5 & 1.6 & 1.6 & 1.7 & 1.7 & 1.8 & 1.7 \\
\hline
\end{tabular}

\subsubsection{Summary - Recent R\&D studies}

The simulation and experimental results of several different heat pump cycles were presented that showed sufficient capacity and performance at low outdoor temperatures. VI and two-stage cycles have similar performance improvements compared to conventional single-stage ASHPs for cold climates. The two-stage cycle presents an easier commercialization path due to the use of off-the-shelf components. Additional field testing is required to further validate the technology as market ready due to complications seen in pervious field testing.

\subsection{Current activities related to Annex 41}


Both analytical and experimental activities are underway at ORNL with a goal to achieve the performance targets outlined in Table $1-$ e. g. heat pump space heating capacity at $-25^{\circ} \mathrm{C}$ $\left(-13^{\circ} \mathrm{F}\right)$ to be $\geq 75 \%$ of the nominal rated heating capacity at $8.3 \mathrm{C}(47 \mathrm{~F})$. Shen (2013) reported on continuing system optimization studies involving single-speed compressor ASHP systems with the two $\mathrm{VI}$ cycle configurations shown in Figure 14 and an alternative design combining an ejector with a flash tank, shown in Figure 20. For the ejector cycle analyses isentropic efficiencies for the throttling, suction, and expansion processes in the ejector were assumed to be $90 \%$. The studies are also examining a number of variable-capacity approaches.
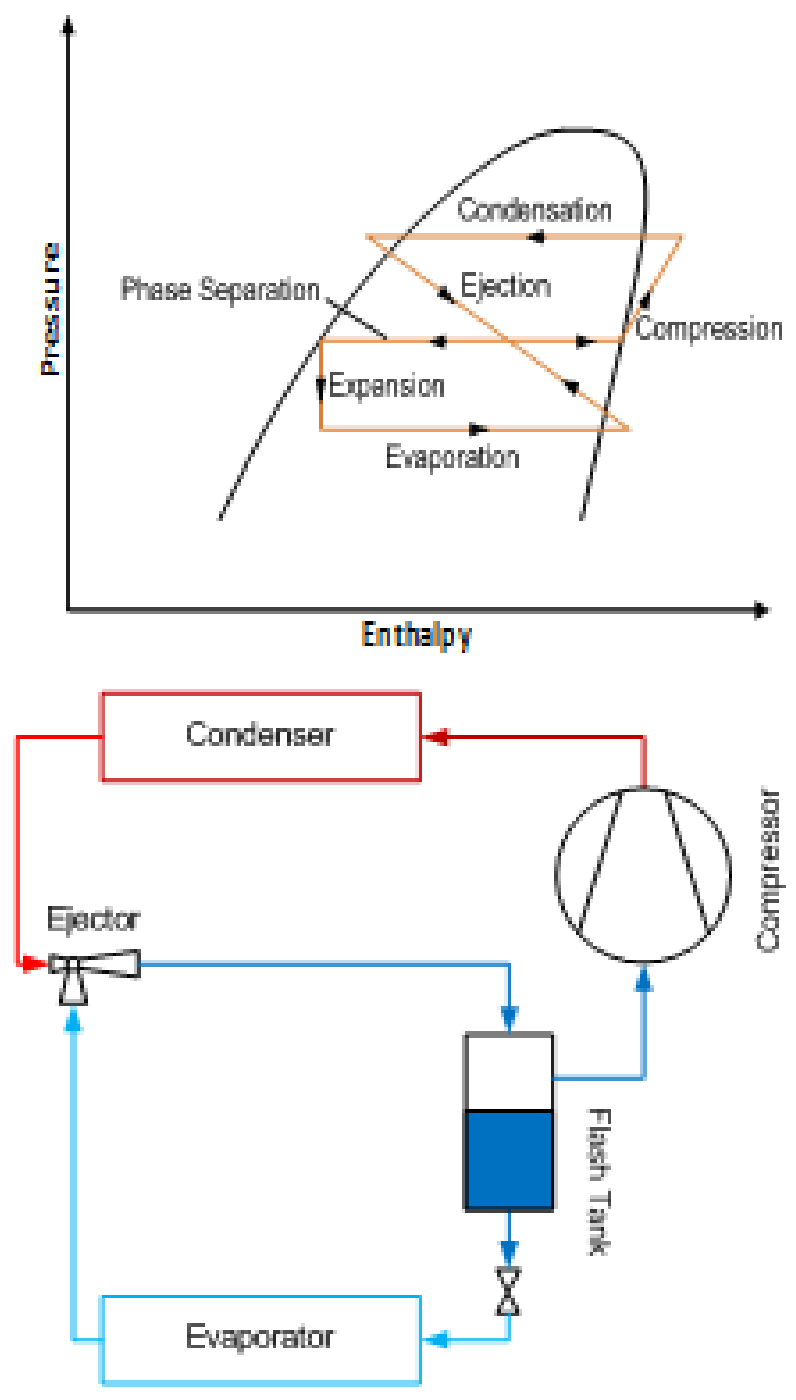

Figure 20: Schematic of flash tank cycle combined with ejector

Results from analyses of the ejector/flash tank cycle vs. the flash tank and economizer VI cycles are shown in Figure 21. Note that the results shown in Figure 21 have been normalized to a baseline single-speed ASHP having a heating seasonal performance factor (HSPF) of 9.6 
Btu/Wh (2.8 W/W) - rated per AHRI Standard 210/240 (AHRI, 2008). Results indicate an efficiency and low-temperature heating capacity advantage by combining the ejector with the flash tank vs. the VI systems (subject to the ejector efficiency assumption). However, Shen (2013) noted that using a multi-stage VI type cycle or an ejector with a flash tank alone is not likely to be sufficient to meet the capacity target (<25\% capacity reduction from nominal). Some form of variable capacity control to boost heating output at low ambient conditions will be required.
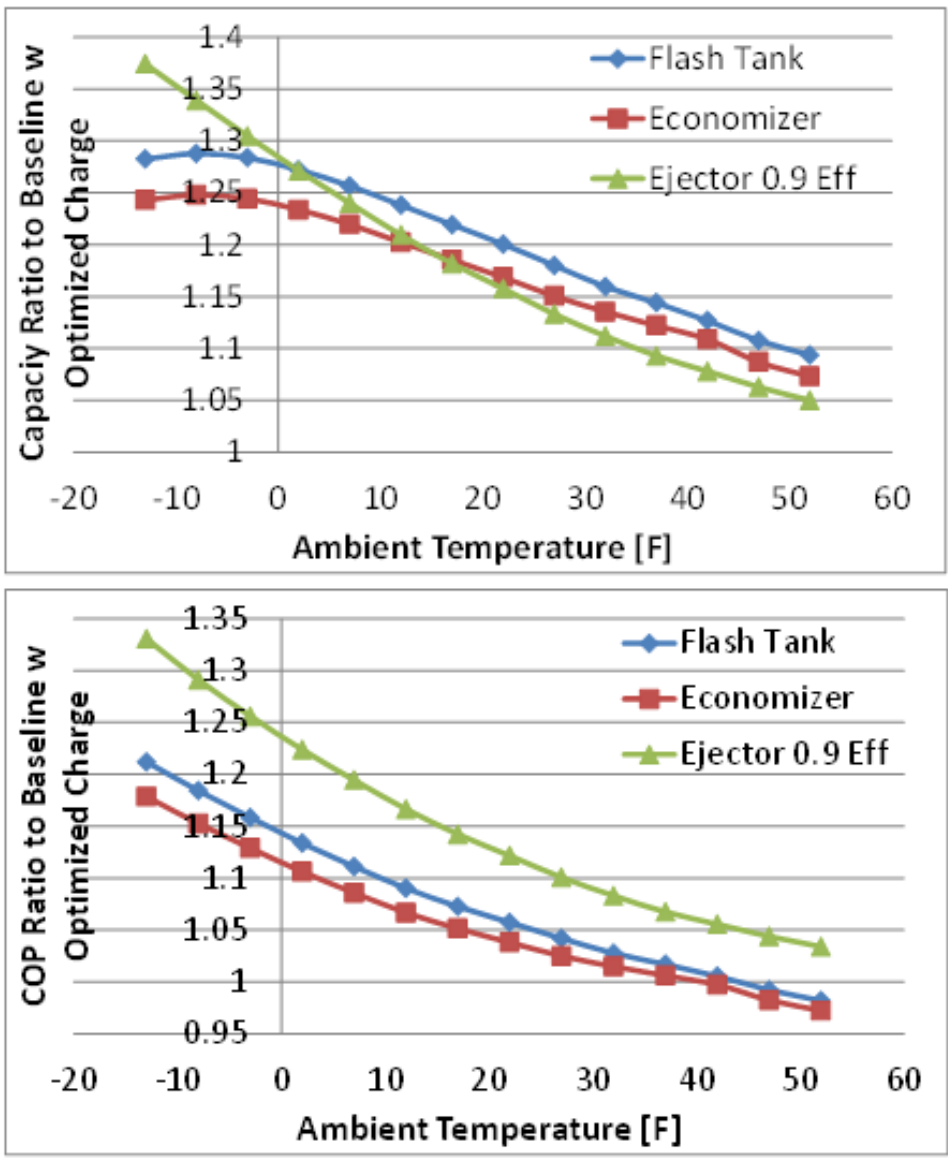

Figure 21: Capacity and COP comparisons of VI cycles to baseline single-speed system

Shen et al. (2013) analytically investigated several variable-capacity options for cold climate ASHPs to determine their potential to achieve the CCHP performance goals as outlined in Table 1. The analyses are based on manufacturers' compressor maps and calibrated system and heat exchanger models developed by ORNL (Shen and Rice, 2012; Shen et al., 2012a; Shen et al., 2012b; Mahderekal et al., 2012). Ten system design and sizing options are listed in Table 5. In general only a fraction of a system's maximum cooling capacity is used to match the building design cooling load while the excess capacity is used to help the system better match the heating demand at low ambient temperatures.

Table 5: ASHP design and sizing options 


\begin{tabular}{|c|c|}
\hline$\#$ & Equipment Sizing Scenarios \\
\hline 1 & $\begin{array}{c}\text { Single speed heat pump having SEER of 13.0, HSPF of 9.6: sized such that rated cooling capacity } \\
\text { matches building design cooling load. }\end{array}$ \\
\hline 2 & $\begin{array}{c}\text { Single HP, having a 2-stage scroll compressor: sized such that rated high-stage (100\%) cooling } \\
\text { capacity matches building design cooling load. }\end{array}$ \\
\hline 3 & $\begin{array}{c}\text { Single HP, having a 2-stage scroll compressor: sized such that rated low-stage (67\%) cooling } \\
\text { capacity matches building design cooling load. }\end{array}$ \\
\hline 4 & $\begin{array}{c}\text { Single HP, having a variable speed (VS) scroll compressor: sized such that rated cooling capacity } \\
\text { at 2700 RPM matches building design cooling load. }\end{array}$ \\
\hline 5 & $\begin{array}{c}\text { Single HP, having a VS scroll compressor: sized such that rated cooling capacity at 3600 RPM } \\
\text { matches building design cooling load. }\end{array}$ \\
\hline 6 & $\begin{array}{c}\text { Single HP, having a VS scroll compressor: sized such that rated cooling capacity at 4500 RPM } \\
\text { matches building design cooling load. }\end{array}$ \\
\hline 7 & $\begin{array}{c}\text { Single HP, having a 2-stage scroll compressor: sized such that 80\% of rated cooling capacity } \\
\text { matches building design cooling load. }\end{array}$ \\
\hline 8 & $\begin{array}{c}\text { Single HP, having a tandem scroll compressor pair: sized such that rated cooling capacity with one } \\
\text { compressor matches building design cooling load. }\end{array}$ \\
\hline 9 & $\begin{array}{c}\text { Single HP, having a single-speed VI scroll compressor: sized such that rated cooling capacity } \\
\text { matches building design cooling load. }\end{array}$ \\
\hline 10 & $\begin{array}{c}\text { Two identical single speed heat pumps, having SEER of 13.0, HSPF of 9.6: sized such that rated } \\
\text { cooling capacity of one unit matches building design cooling load; both units used for heating. }\end{array}$ \\
\hline
\end{tabular}

Note: All VS compressor system options have a speed range of 1800 - 7200 RPM; option 8, tandem compressor pair contains two identical compressors; the 2-stage compressor options include one compressor having two capacity levels, i.e. $100 \% / 67 \%$.

For each of the 10 ASHP systems, Table 6 lists the heating capacity ratio, defined as the ratio of the $-25^{\circ} \mathrm{C}\left(-13^{\circ} \mathrm{F}\right)$ heating capacity at the highest speed (or compressor stage) to the nominal heating capacity at $8.3^{\circ} \mathrm{C}\left(47^{\circ} \mathrm{F}\right)$, and the heating COPs at $8.3^{\circ} \mathrm{C}$ and $-25^{\circ} \mathrm{C}$. Four of the options $(4,5,8$, and 10$)$ have estimated capacity ratios near the target level. COPs at $-25^{\circ} \mathrm{C}$ for these options range around $45-55 \%$ of the nominal COPs at $8.3^{\circ} \mathrm{C}$. Estimated Heating Seasonal Performance Factor ratings (HSPF) are calculated based on the method prescribed in AHRI Standard 210/240 (AHRI, 2008) for US region IV (mildly cold climate).

Table 6: Predicted ASHP System Performance Indices - from ORNL and HSPF (AHRI, 2008) calculations

\begin{tabular}{|c|c|c|c|c|}
\hline Options & $\begin{array}{c}\mathbf{C O P} @ \\
\mathbf{8 . 3}^{\circ} \mathbf{C}\left(\mathbf{4 7}^{\circ} \mathbf{F}\right)\end{array}$ & $\begin{array}{c}\text { Heating } \\
\text { Capacity } \\
\text { Ratio @-25 } \\
\left(-\mathbf{- 1 3}^{\circ} \mathbf{C}\right)\end{array}$ & $\begin{array}{c}\mathbf{C O P} @ \mathbf{C - 2 5}^{\circ} \mathbf{C} \\
\left.\mathbf{( - 1 3}^{\circ} \mathbf{F}\right)\end{array}$ & $\begin{array}{c}\text { Region IV HSPF } \\
\text { rating }\end{array}$ \\
\hline & {$[\mathbf{W} / \mathbf{W}]$} & {$[-]$} & {$[\mathbf{W} / \mathbf{W}]$} & {$[\mathbf{W} / \mathbf{W}(\mathbf{B t u} / \mathbf{W h})]$} \\
\hline 1. & 3.58 & $40 \%$ & 1.92 & $2.80(9.55)$ \\
\hline 2. & 3.79 & $42 \%$ & 2.09 & $2.92(9.96)$ \\
\hline 3. & 3.78 & $57 \%$ & 2.09 & $2.92(9.98)$ \\
\hline 4. & 4.30 & $94 \%$ & 1.89 & $3.40(11.61)$ \\
\hline 5. & 4.14 & $74 \%$ & 1.89 & $3.43(11.71)$ \\
\hline 6. & 3.80 & $61 \%$ & 1.89 & $3.40(11.59)$ \\
\hline 7. & 3.79 & $52 \%$ & 2.09 & $2.95(10.05)$ \\
\hline
\end{tabular}




\begin{tabular}{|r|c|c|c|c|}
\hline 8. & 4.38 & $75 \%$ & 1.98 & $3.31(11.31)$ \\
\hline 9. & 3.75 & $43 \%$ & 2.12 & $2.96(10.09)$ \\
\hline 10. & 3.58 & $80 \%$ & 1.92 & N/A \\
\hline
\end{tabular}

Figure 22 graphically illustrates these results for options 4-6 and 8 along with similar estimates for the baseline, VI, and ejector system options. The figure shows that the two largest VS systems and the tandem compressor system all can meet the capacity target but efficiency suffers compared to the VI and ejector cycles. Investigation of combining variable capacity approaches with VI to boost low-temperature efficiency is continuing - one option is the twostage compressor with economizer cycle (illustrated in Figure 11, middle).

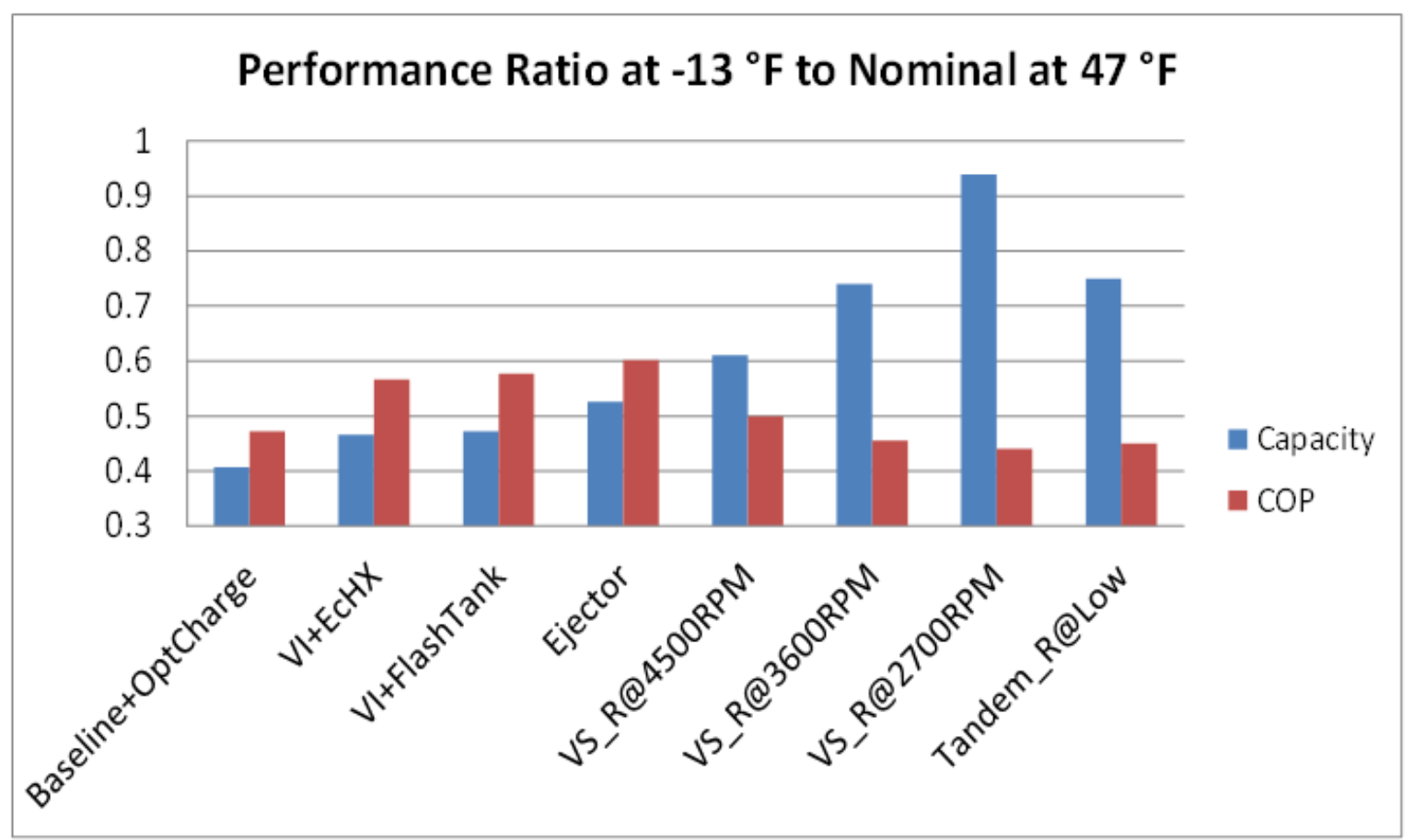

Figure 22: Capacity and COP comparisons of VI cycles to baseline single-speed system

Abdelaziz (2013) describes ongoing and planned experimental activities to complement these analytical activities. A split ASHP system (R-410A refrigerant) has been fitted with an ejector and some initial tests have been run (see Figure 23, below, for ejector design). The results show that a compressor suction pressure boost of about $40-55 \mathrm{kPa}(6-8 \mathrm{psi})$ can be achieved with the initial ejector design employed. However, it is observed that the combination of a fixedsize ejector and a flash tank has a limited working range, which is not able to cover the whole of the heating conditions. Plans call for the test system to be modified with a tandem compressor pair to boost the heating capacity, and a combination of ejector and flash tank specially sized for low ambient temperatures, for example, below $-18^{\circ} \mathrm{C}\left(\sim 0^{\circ} \mathrm{F}\right)$, to boost the heating capacity and operation efficiency at extremely low temperature, as illustrated in Figure 24. 


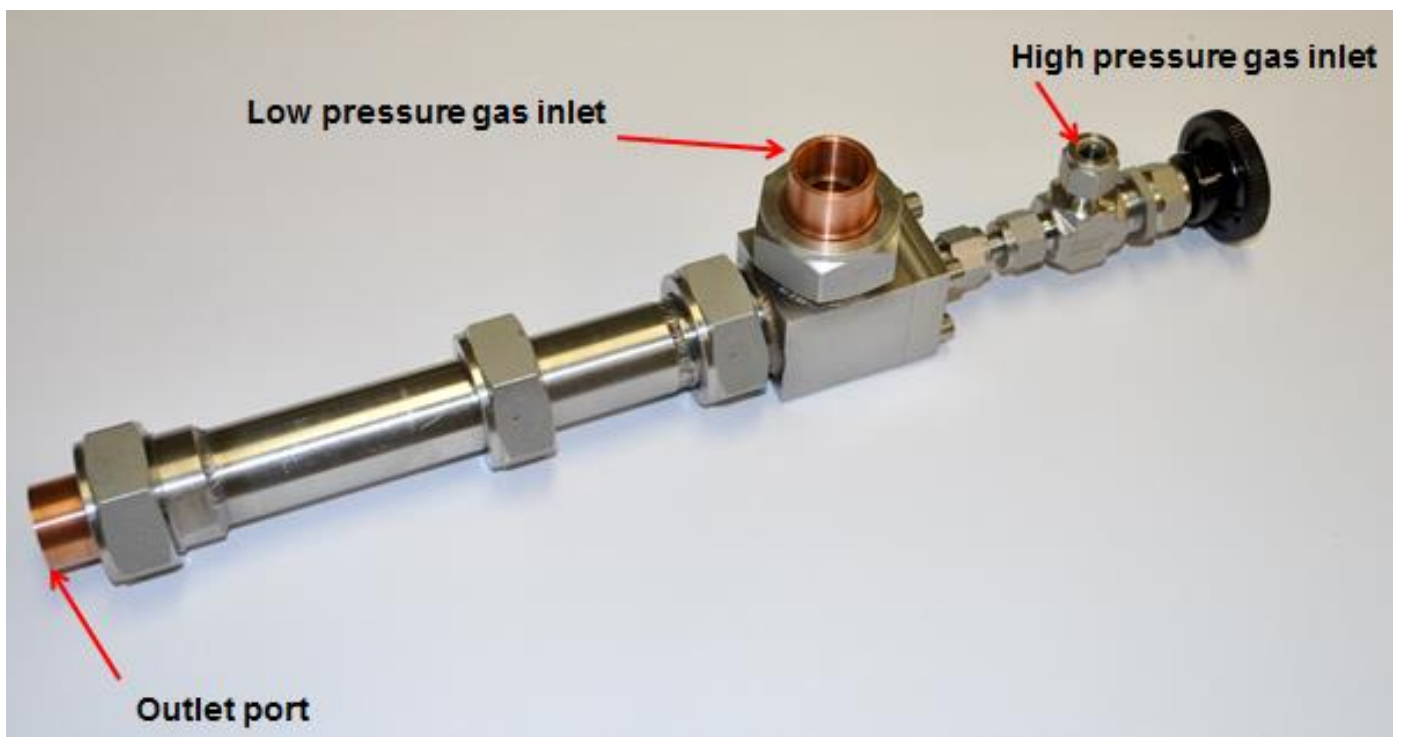

Figure 23: Ejector prototype design for ORNL lab test system

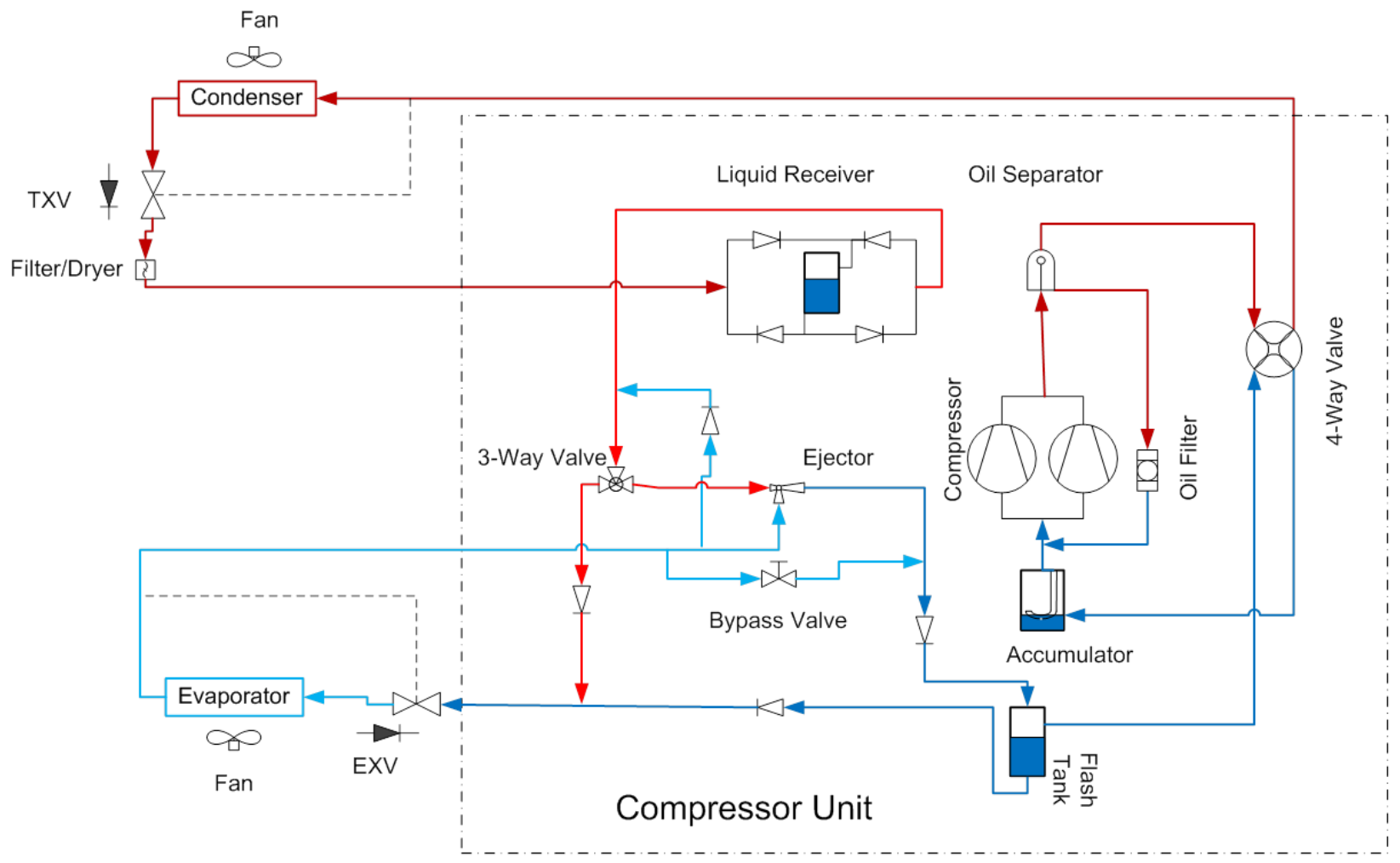

Figure 24: Enhanced ejector cycle design, using tandem compressor pair and turning on the ejector only at low ambient temperatures 
At Purdue, laboratory testing of systems incorporating $\mathrm{VI}$ and oil-flooded compressors are in progress (Bach et al., 2013). A VI test system (using a split system heat pump) has been installed and is being debugged. In addition, an oil-flooded test set up (using a packaged heat pump) has been constructed and the installation is close to being finished. Figure 25 shows the schematic of the oil-flooded system. In HP mode, the internal heat exchanger and oil cooler are active and oil injection is used. For AC mode, both heat exchangers are bypassed and the compressor is run without oil injection.

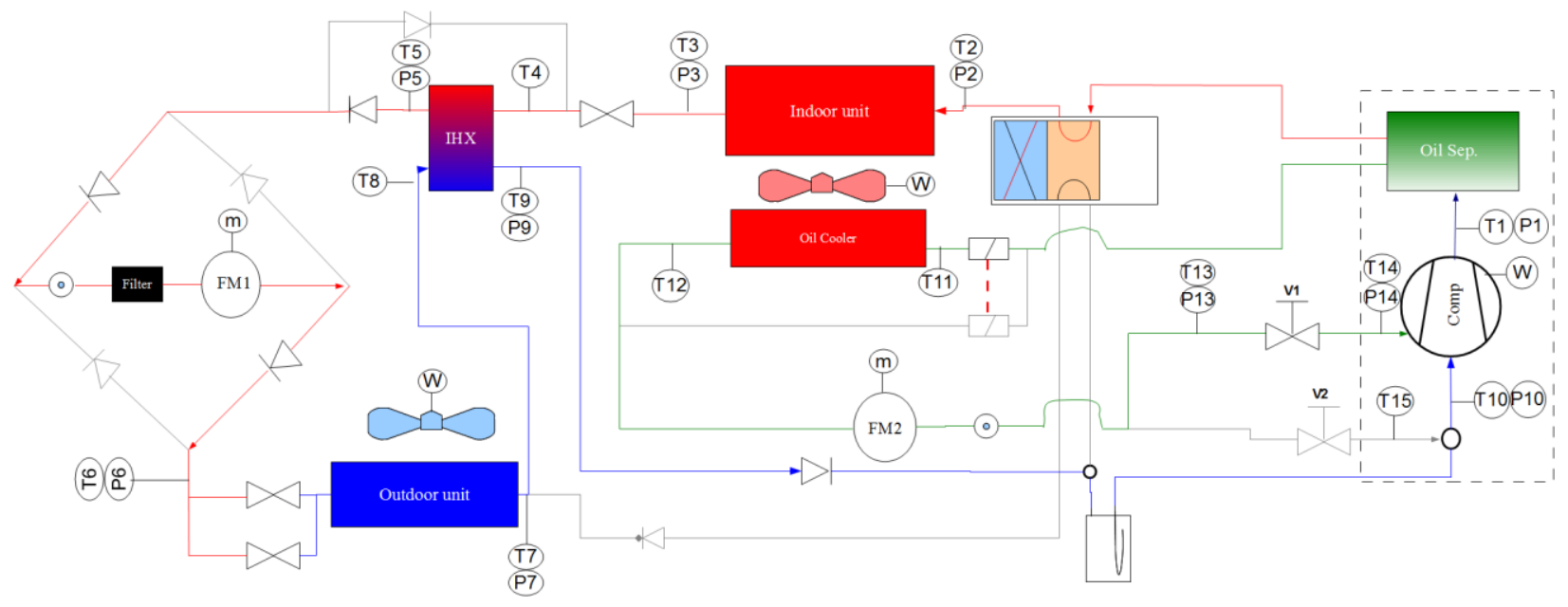

Figure 25: System schematic for oil-flooded heat pump

The oil-flooded system will be operated at the standard AHRI 210/240 (2008) testing conditions with 6 different oil injection rates, ranging from 0 to $30 \%$ of the total compressor flow rate. In addition to the standard ASHP heating testing conditions (AHRI, 2008), a low ambient temperature condition $\left(0^{\circ} \mathrm{F}\right)$ will be tested. Cooling or air-conditioning (AC) mode tests will be conducted to determine possible system efficiency penalties due to the system changes in that operating mode.

A field test of an advanced ASHP designed for cold climate operation has been completed at Camp Atterbury Army base in Indiana (Caskey et al., 2013). The heat pump is a twocompressor (two-stage) system with an economizer VI loop, similar to the concept analyzed by Bertsch, et al. (2008). It features a large tandem scroll compressor for low ambient temperature capacity boosting and a VS scroll for cooling operation and moderate ambient heating. The test is being conducted under the DOD's Energy Security Technology Certification Program (ESTCP). Two, identical military barracks from available buildings located at Camp Atterbury, outside Edinburgh, Indiana, were selected for the field demonstration. The originally installed HVAC system was a natural gas furnace with a split system air conditioner. A side-by-side performance comparison between the originally installed HVAC system and the two precommercial heat pump units developed at Purdue University was conducted during the 20122013 heating season. Only commercially available components were selected for all parts of the heat pump units with help from three industrial partners, namely Ingersoll Rand - The Trane Company, Emerson Climate Technology, and Danfoss. The heat pump units had a design heating capacity of $18.34 \mathrm{~kW}(62,580 \mathrm{BTU} / \mathrm{h})$ at an ambient temperature of $-20^{\circ} \mathrm{C}\left(4^{\circ} \mathrm{F}\right)$. 
The heat pump performance was compared to the existing HVAC system using six performance objectives that are listed in Table 7 . The objective of the project is to reach or surpass the success criteria listed for each performance objective.

Table 7: ESTCP project performance objectives of the cold climate heat pump

\begin{tabular}{|l|c|c|c|}
\hline \multicolumn{1}{|c|}{$\begin{array}{c}\text { Performance } \\
\text { Objective }\end{array}$} & Metric & Data Requirements & Success Criteria \\
\hline \multicolumn{4}{|c|}{ Quantitative Performance Objectives } \\
\hline $\begin{array}{l}\text { 1. Reduce primary } \\
\text { energy for heating } \\
\text { (Energy) }\end{array}$ & Therms or kW-hr & $\begin{array}{c}\text { Electric and gas use } \\
\text { metered }\end{array}$ & $\begin{array}{c}\text { Reduce primary } \\
\text { energy use by } 25 \%\end{array}$ \\
\hline $\begin{array}{l}\text { 2. Reduce costs } \\
\text { (Finances) }\end{array}$ & $\$$ & $\begin{array}{c}\text { Base rates for } \\
\text { electricity and fuel }\end{array}$ & $\begin{array}{c}10 \% \text { reduction in } \\
\text { heating costs }\end{array}$ \\
\hline $\begin{array}{l}\text { 3. Reduce } \\
\text { emissions } \\
\text { (Environment) }\end{array}$ & $\begin{array}{c}\text { Metric ton } \mathrm{CO}_{2} \\
\text { equivalent }\end{array}$ & $\begin{array}{c}\text { Conversions for fuels } \\
\text { Qualitative Performans } \mathrm{CO}_{2} \\
\text { emissions } 15 \%\end{array}$ \\
\hline $\begin{array}{l}\text { 4. Ease of } \\
\text { installation }\end{array}$ & $\begin{array}{c}\text { Ability of a technician- } \\
\text { level individual to install } \\
\text { the heat pump }\end{array}$ & $\begin{array}{c}\text { Feedback from the } \\
\text { technicians on } \\
\text { installation time }\end{array}$ & $\begin{array}{c}\text { A field technician } \\
\text { team is able to install } \\
\text { the system }\end{array}$ \\
\hline 5. Maintenance & $\begin{array}{c}\text { Ability of a technician- } \\
\text { level individual to } \\
\text { maintain the heat pump }\end{array}$ & $\begin{array}{c}\text { Feedback from the } \\
\text { technicians on } \\
\text { maintenance calls }\end{array}$ & $\begin{array}{c}\text { A field technician } \\
\text { team is able to } \\
\text { operate the system }\end{array}$ \\
\hline 6. Comfort & $\begin{array}{c}\text { Maintain temperature } \\
\text { within comfort range of } \\
\text { building occupants }\end{array}$ & $\begin{array}{c}\text { Indoor temperature } \\
\text { readings and survey of } \\
\text { occupants }\end{array}$ & $\begin{array}{c}80 \% \text { of occupants } \\
\text { satisfied with indoor } \\
\text { conditions }\end{array}$ \\
\hline
\end{tabular}

Caskey et al. (2013) discussed results of the field test from the 2012-2013 heating season in general comparison with the criteria listed in Table 7. For the monitored period at the Army site the ASHP system achieved about 19\% source energy savings vs. the baseline gas furnace system but utility costs were higher due to the low price the Army pays for natural gas at the site. Using average Indiana residential electricity and gas prices the utility costs for the ASHP and baseline furnace would have been about the same. The ASHP used no electric back up heating during the test period. Using ASHRAE Standard 55 (ASHRAE, 2010) to evaluate the thermal comfort indicated that the heat pump was able to maintain comfort levels throughout the heating season. Furthermore, the installation and maintenance cost and complexity of the heat pump is comparable to those of conventional air-source heat pumps.

Full commercialization of the air-source, two-stage heat pump with economizing is now continuing in partnership with a U. S. heat pump system manufacturer. The company was recently awarded a two-year contract from the U.S. Department of Energy for the commercialization of a cold climate heat pump and has licensed the two heat pump patents owned by Purdue University. They have also signed a research agreement with Purdue University, which outlines the support by the research team for the ongoing work towards full commercialization. 
All of the advanced ASHP system concepts discussed above can result in improved performance under extreme cold outdoor conditions. All address in one way or another the key challenge for electric-driven ASHPs under these conditions - to maintain or boost heating capacity and thereby reduce usage of back up electric resistance heating, thus yielding better heating SPFs. They also have another characteristic in common - all involve increased system complexity which will result in increased cost compared to conventional ASHPs. It is possible that one or more of these approaches could result in a technically feasible ASHP that achieves heating SPF parity with GSHPs, gas-driven ASHPs, or other residential HVAC systems in cold climate locations. Whether this can be achieved at lower installed costs than the aforementioned alternative systems remains to be seen.

\section{ACKNOWLEDGEMENTS}

The assembly of this report and the ORNL technical activities described herein are supported by the U. S. Department of Energy, Building Technologies Office (DOE/BTO) under Contract No. DE-AC05-00OR22725 with UT-Battelle, LLC. The official report number is ORNL/TM-2013/472.

\section{$7 \quad$ REFERENCES}

Abdelaziz O. A., B. Shen, Z. Gao, V. D. Baxter, and I. Iu. 2011. "Development of a high performance air source heat pump for the US market." Proceedings of the $10^{\text {th }}$ IEA Heat Pump Conference, Tokyo, Japan. CD rom format only.

Abdelaziz O. A. and B. Shen. 2012. "Cold Climates Heat Pump Design Optimization," ASHRAE Transactions, Vol. 112, Part 1.

Abdelaziz O. A. 2013. "ORNL Cold Climate - Experimental Investigations," presentation at Annex $41,1^{\text {st }}$ Working Meeting, Purdue University, July 1.

AHRI 2008. ANSI/AHRI Standard 210/240-2008, "Performance Rating of Unitary AirConditioning and Air Source Heat Pump Equipment," Air-Conditioning, Heating, and Refrigeration Institute, Arlington, VA, USA.

AHRI 2010-2013. Central Air Conditioners and Air-Source Heat Pumps Historical Data. Retrieved from AHRI website (www.ahrinet.org) in December 2010 and in August 2013).

AHRI 2012. "HVAC\&R \& Water Heating Industry Statistical Profile," 2012 Edition.

ASHRAE 2010. ANSI/ASHRAE Standard 55-2010, "Thermal Environmental Conditions for Human Occupancy," American Society of Heating, Refrigerating, and Air-Conditioning Engineers, Atlanta, GA, USA.

Bach C. K., J. A. Braun, E. A. Groll, and W. T. Horton. 2013. "Cold Climate Heat Pumps Performance improvement by modification of compression process and cycle," presentation at Annex 41, $1^{\text {st }}$ Working Meeting, Purdue University, July 1. 
Bell I. H. 2011. "Theoretical and Experimental Analysis of Liquid Flooded Compression in Scroll Compressors," PhD Thesis, Herrick Laboratories, Purdue University, West Lafayette, IN, USA.

Bell I. H., E. A. Groll, and J. E. Braun. 2011. "Performance of Vapor Compression Systems with Compressor Oil Flooding and Regeneration," International Journal of Refrigeration, Vol. 34, No. 1, pp. 225-233.

Bertsch S. S. 2005. "Theoretical and experimental investigation of a two stage heat pump cycle for Nordic climates," (Doctoral dissertation, Master's thesis, Mechanical Engineering, Herrick Labs 2005-13P, Report).

Bertsch S. S. and E. A. Groll. 2006. "Air Source Heat Pump for Northern Climates Part I: Simulation of Different Heat Pump Cycles," Proceedings of the $11^{\text {th }}$ International Refrigeration and Air Conditioning Conference at Purdue.

Bertsch S. S. and E. A. Groll. 2008. "Two-stage air-source heat pump for residential heating and cooling applications in northern US climates," International Journal of Refrigeration, Vol. 31(7), pp. 1282-1292.

Bucher M. E., C. M. Grastataro, and W. Coleman. 1989. "Heat Pump Life and Compressor Survival in Diverse Climates," EPRI Report No. CU-6254, February 1989 (AEP).

Bullock C. E. 1978. "Energy Savings through Thermostat Setback with Residential Heat Pumps," ASHRAE Transactions, Vol. 84, Part 1.

Bullock C. E., G. C. Groff, and W. R. Reedy. 1980. "Sizing of Air-to-Air Heat Pumps for Northern Climate Residential Heating Applications," Proceedings of the International HVAC Congress, Berlin, Germany, April 17-18.

Caskey S. L., E. A. Groll, and W. J. Hutzel. 2013. "Cold Climate Heat Pump Field Demonstration of Air-Source Heat Pump with Two-Stage Compression and Economizing," presentation at Annex 41, $1^{\text {st }}$ Working Meeting, Purdue University, July 1.

Caskey S. L. 2013. "Cold Climate Field Test Analysis of an Air-Source Heat Pump With TwoStage Compression and Economizing," Master's Thesis, Purdue University, Ray W. Herrick Laboratories, West Lafayette, IN.

Census Bureau, U.S. 2013. Census Bureau's Characteristics of New Single-Family Homes Reports.

Conti, J., and P. Holtberg. 2011. "International Energy Outlook 2011," Washington: Independent Statistics and Analysis of US Energy Information Administration.

Department of Defense, U.S., Energy Security Task Force, Office of the Under Secretary of Defense. 2009. The WSTIAC Quarterly, Vol. 9, No. 1.

Department of Energy, U.S. 2011. "Buildings Energy Databook," Office of Energy Efficiency \& Renewable Energy.

Energy Independence and Security Act of 2007. Public Law, (110-140), 2. 
Energy Information Administration, U.S. (EIA) 2009. "Residential Energy Consumption Survey," Tables HC6.8, HC6.9, HC6.10, and HC6.11. Accessed September 2013.

Energy Information Administration, U.S. (EIA) 2013. "Annual Energy Outlook (AEO)." Early Release Overview, Release Date: December 5, 2012, Report Number: DOE/EIA-0383ER.

Energy Information Administration, U.S. (EIA) 2013. "Annual Energy Outlook 2013," DOE/EIA0383(2013), retrieved September 2013.

Executive Order. 2009. 13514. Federal Leadership in Environmental, Energy, and Economic Performance.

Groff G. C. and W. R. Reedy. 1978. "Investigation of Heat Pump Performance in the Northern Climate through Field Monitoring and Computer Simulation," ASHRAE Transactions, Vol. 84, Part 1.

Groff G. C., C. E. Bullock, and W. R. Reedy. 1978. "Heat Pump Performance Improvements for Northern Climate Applications," pp. 838-846 in Proceedings of the $13^{\text {th }}$ International Energy Conversion Engineering Conference, San Diego, CA, USA, September. Society of Automotive Engineers. Paper no. 789455.

Groff G. C., W. R. Reedy, and C. E. Bullock. 1979. "Recent Investigation of Air-Source Heat Pump Performance in Cold Climates," Paper E1-25 in Proceedings of the $15^{\text {th }}$ International Congress of Refrigeration, Venice, Italy, September 23-29. International Institute of Refrigeration.

Groff G. C. and J. P. Moreau. 1983. "An Investigation of Air-to-Water Heat Pump Performance in New and Existing French Homes," ASHRAE Transactions, Vol. 89, Part 1.

Groff G. C. and R. E. Ertinger. 1984. "Heat Pumps in the USA - Projections for the Future," Published in the Proceedings of the $1^{\text {st }}$ International Energy Agency Heat Pump Conference, Graz, Austria, May.

Groff G. C., C. E. Bullock, and R. E. Hough. 1984. "An Investigation of Electric Heat Pumps Applied to Commercial Buildings," Published in the Proceedings of the $1^{\text {st }}$ International Energy Agency Heat Pump Conference, Graz, Austria, May.

Hadley A., J. Callahan, and R. Stroh. 2006. "Without strip heat: In-Situ monitoring of a multistage air source heat pump in the Pacific Northwest," Bonneville Power Administration.

Khowailed G., K. G. Sikes, and O. A. Abdelaziz. 2011. "Preliminary Market Assessment for Cold Climate Heat Pumps," Oak Ridge National Laboratory report ORNL/TM-2011/422, August.

Kwon O., D. Cha, and C. Park. 2013. "Performance evaluation of a two-stage compression heat pump system for district heating using waste energy," Energy.

Lannus A. 1993. "Expanding the Limits: Heat Pump Technology and markets in North America," p. 373-380 in Heat Pumps for Energy Efficiency and Environmental Progress. Proceedings of the $4^{\text {th }}$ International Energy Agency Heat Pump Conference, Maastricht, The Netherlands, April 26-29. 
Lapsa M. and G. Khowailed. 2011. "The Evolution of the U.S. Heat Pump Market," Proceedings of the $10^{\text {th }}$ International Energy Agency Heat Pump Conference, Tokyo, Japan.

Lovvorn N., C. C. Hiller, and A. Bartolucci. 2001. "Heat Pump Life in Alabama-Revisited: A Follow-Up Survey 13 Years Later," EPRI, Palo Alto, CA, and Alabama Power Company, Birmingham, AL: 2001. 1006265.

Lovvorn N. and C. C. Hiller. 2002. "Heat Pump Life Revisited," ASHRAE Transactions, Vol. 108, Part 2.

Mahderekal I., B. Shen, E. A. Vineyard. 2012. "System Modeling of Gas Engine Driven Heat Pump," Proceedings of $14^{\text {th }}$ International Refrigeration and Air Conditioning Conference at Purdue, West Lafayette, IN.

Mathison M. M., J. E. Braun, and E. A. Groll. 2011. "Performance Limit for Economized Cycles with Continuous Refrigerant Injection," International Journal of Refrigeration, Vol. 34, pp. 234242.

Mathison M. M. 2011. "Modeling and Evaluation of Advanced Compression Techniques for Vapor Compression Equipment," PhD Thesis, Purdue University, Ray W. Herrick Laboratories, West Lafayette, IN.

Pientka K. A. 1987. "Heat Pump Service Life and Compressor Longevity in a Northern Climate," ASHRAE Transactions, Vol. 93, Part 1.

Ramaraj S. 2012. "Vapor compression enhancements for cold climate heat pumps," Master Thesis, Herrick Laboratories, Purdue University, West Lafayette, IN, USA.

Ratts E. B. and J. S. Brown. 2000. "A generalized analysis for cascading single fluid vapor compression refrigeration cycles using an entropy generation minimization method," International Journal of Refrigeration, Vol. 23(5), pp. 353-365.

Rohm C. W. and M. S. Kim. 2011. "Effects of intermediate pressure on the heating performance of a heat pump system using R410A vapor-injection technique," International Journal of Refrigeration, Vol. 34(8), pp. 1911-1921.

Roth K. W., D. Westphalen, J. Dieckmann, S. D. Hamilton, \& W. Goetzler. 2002. "Energy consumption characteristics of commercial building HVAC systems Volume III: Energy savings potential," Report prepared by TIAX LLC for DOE Building Technologies Program.

Ryan J. D. and G. C. Groff. 2002. North American Market Overview. pp. 26-37 in Heat Pumps Better by Nature. Proceedings of the $7^{\text {th }}$ International Energy Agency Heat Pump Conference, Beijing, China, May 19-22.

Shen B. and C. K. Rice. 2012. "Multiple-Zone Variable Refrigerant Flow System Modeling and Equipment Performance Mapping," Conference CD of ASHRAE 2012 Winter Conference, Chicago, IL.

Shen B., O. Abdelaziz, and C. K. Rice. 2012a. "Auto-Calibration and Control Strategy Determination for a Variable-Speed Heat Pump Water Heater Using Optimization," HVAC\&R Research, Vol. 18(5), pp. 904-914, 2012. 
Shen B., C. K. Rice., and E. A. Vineyard. 2012b. "Development of 20 IEER Rooftop Units - A Simulation Study," Proceedings of $14^{\text {th }}$ International Refrigeration and Air Conditioning Conference at Purdue, West Lafayette, IN.

Shen B. 2013. "Cold Climate Heat Pump - ORNL System Modeling and Analysis," presentation at Annex $41,1^{\text {st }}$ Working Meeting, Purdue University, July 1.

Shen, B., S. S. Shrestha, and O. A. Abdelaziz. 2013. "Assessment of Main Strategies for Achieving Performance Targets for Cold Climate Heat Pump," draft ORNL Report (under review), February, 2013.

Song. 2013. "Modeling and experimental validation of multi-port vapor injected scroll compressor," Master Thesis, Herrick Laboratories, Purdue University, West Lafayette, IN, USA.

Wang S. and A. Majumdar. 2004. "Digital Scroll Technology," ISHRAE Journal, January-March, Issue 2004.

Wang X., Y. Hwang, and R. Radermacher. 2009. "Two-stage heat pump system with vaporinjected scroll compressor using R410A as a refrigerant," International Journal of Refrigeration, Vol. 32(6), pp. 1442-1451.

Xu X., Y. Hwang, and R. Radermacher. 2011. "Refrigerant injection for heat pumping/air conditioning systems: literature review and challenges discussions," International Journal of Refrigeration, Vol. 34(2), pp. 402-415.

Zubair S. M., M. Yaqub, and S. H. Khan. 1996. "Second-law-based thermodynamic analysis of two-stage and mechanical-subcooling refrigeration cycles," International Journal of Refrigeration, Vol. 19(8), pp. 506-516. 